\title{
The Geomorphology of The Anthropocene: Emergence, Status and Implications
}

Antony G. Brown ${ }^{1}$, Stephen Tooth ${ }^{2}$, Joanna E. Bullard ${ }^{3}$, David S.G. Thomas ${ }^{4}$, Richard C. Chiverrell, Andrew J. Plater ${ }^{5}$, Julian Murton ${ }^{6}$, Varyl R. Thorndycraft ${ }^{7}$, Paolo Tarolli ${ }^{8}$, James Rose ${ }^{7,9}$, John Wainwright ${ }^{10}$, Peter Downs ${ }^{11}$, Rolf Aalto ${ }^{12}$

${ }^{1}$ Palaeoenvironmental Laboratory, University of Southampton (PLUS), Highfields Campus, Southampton, SO17 1BJ, UK. Email: Tony.Brown@soton.ac.uk

${ }^{2}$ Department of Geography and Earth Sciences, Aberystwyth University, Llandinam Building, Aberystwyth, Ceredigion, SY23 3DB, UK. Email: set@aber.ac.uk

${ }^{3}$ Department of Geography, Loughborough University, Leicestershire, LE11 3TU, UK. Email:

J.E.Bullard@lboro.ac.uk

${ }^{4}$ School of Geography and Environment, Oxford University Centre for the Environment, South Parks Road, Oxford, OX1 3QY, UK. Email: david.thomas@ouce.ox.ac.uk

${ }^{5}$ Department of Geography and Planning, School of Environmental Sciences, Roxby Building, Chatham Street, Liverpool, L69 7ZT, UK. Email: rchiv@liverpool.ac.uk or gg07@liverpool.ac.uk

${ }^{6}$ Permafrost Laboratory, Department of Geography, University of Sussex, Brighton BN1 9QJ, UK. Email:

J.B.Murton@sussex.ac.uk

7Department of Geography, Royal Holloway, University of London, Egham, Surrey, TW20 OEX, UK. Email:

Varyl.Thorndycraft@royalholloway.ac.uk

${ }^{8}$ Department of Land, Environment, Agriculture and Forestry, University of Padova, Italy. Email:

paolo.tarolli@unipd.it

${ }^{9}$ British Geological Survey, Keyworth, Notts, NG12 5GG, UK. Email: jimrose@clara.co.uk

${ }^{10}$ Department of Geography, Durham University, Lower Mountjoy, South Road, Durham, DH1 3LE, UK. Email:

john.wainwright@durham.ac.uk

${ }^{11}$ School of Geography, Earth and Environmental Sciences, Plymouth University, Portland Square, Drake Circus, Plymouth, Devon, PL4 8AA, UK. Email: peter.downs@plymouth.ac.uk

${ }^{12}$ Department of Geography, University of Exeter, Exeter EX4 4RJ. Email: rolf.aalto@exeter.ac.uk

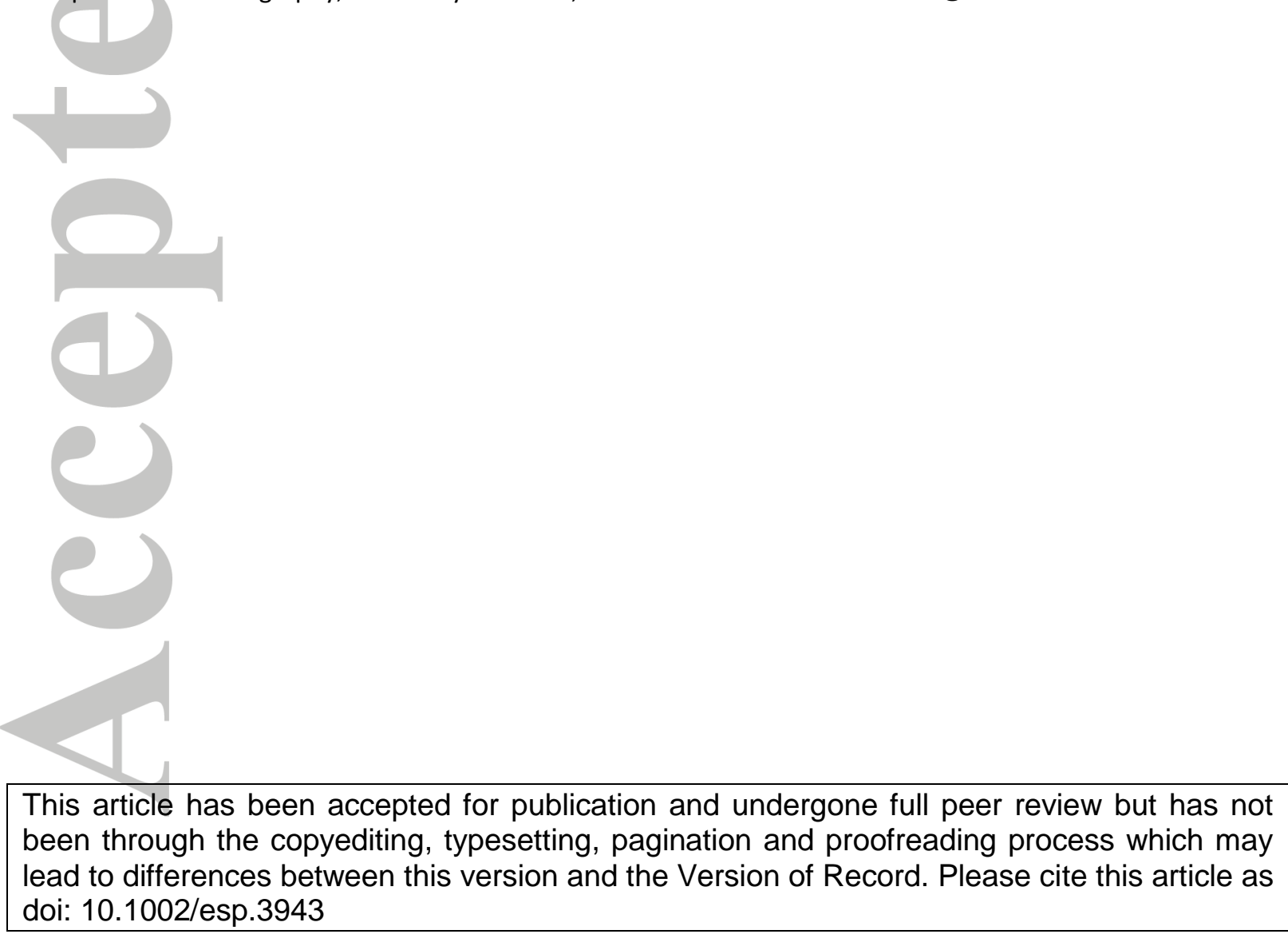

This article is protected by copyright. All rights reserved. 


\section{Abstract}

The Anthropocene is proposed as a new interval of geological time in which human influence on Earth and its geological record dominates over natural processes. A major challenge in demarcating the Anthropocene is that the balance between human-influenced and natural processes varies over spatial and temporal scales owing to the inherent variability of both human activities (as associated with culture and modes of development) and natural drivers (e.g. tectonic activity and sea level variation). Against this backdrop, we consider how geomorphology might contribute towards the Anthropocene debate focussing on human impact on aeolian, fluvial, cryospheric and coastal process domains, and how evidence of this impact is preserved in landforms and sedimentary records. We also consider the evidence for an explicitly anthropogenic geomorphology that includes artificial slopes and other human-created landforms. This provides the basis for discussing the theoretical and practical contributions that geomorphology can make to defining an Anthropocene stratigraphy. It is clear that the relevance of the Anthropocene concept varies considerably amongst different branches of geomorphology, depending on the history of human actions in different process domains. For example, evidence of human dominance is more widespread in fluvial and coastal records than in aeolian and cryospheric records, so geomorphologically the Anthropocene would inevitably comprise a highly diachronous lower boundary. Even to identify this lower boundary, research would need to focus on the disambiguation of human effects on geomorphological and sedimentological signatures. This would require robust data, derived from a combination of modelling and new empirical work rather than an arbitrary 'war of possible boundaries' associated with convenient, but disputed, 'golden spikes'. Rather than being drawn into stratigraphical debates, the primary concern of geomorphology should be with the investigation of processes and landform development, so providing the underpinning science for the study of this time of critical geological transition.

Keywords: aeolian, anthropogenic, coastal, cryosphere, fluvial, stratigraphy 


\section{Introduction}

The Anthropocene has been proposed as a new interval of geological time to account for the 'dominant' or 'overwhelming' influence of human activities on the Earth's surface and its geological record (Crutzen, 2002; Waters et al., 2016). As geomorphology is concerned with understanding Earth surface processes and landforms it cannot logically avoid engagement with the Anthropocene debate (Brown et al., 2013a). Indeed, from the $19^{\text {th }}$ Century onwards, both physical geography and geology have addressed human impacts on the Earth's surface (e.g. Marsh, 1874; Gilbert, 1877; Happ et al., 1940; Hooke, 1994; Church, 2010). This position paper builds on initial considerations by the British Society for Geomorphology's Anthropocene Fixed Term Working Group, which outlined the role of geomorphology in the Anthropocene debate (Brown et al., 2013a), whilst also drawing on similar discussions in allied fields such as Quaternary Science (Gale and Hoare, 2012) and in biology (Caro et al., 2011).

Although it can be argued that "wilderness has effectively gone" (Wohl, 2013, p.4), human impact on the terrestrial environment has varied, and continues to vary, in nature (e.g. directly, indirectly), intensity and duration. This variable impact is highly relevant for key elements of the Anthropocene debate such as the lower boundary problem (Brown et al., 2013a). If we recognise that human activities now dominate over natural processes over the vast majority of the Earth's surface, just when did this dominance start and so usher in a new geological interval (Lewis and Maslin, 2015; Waters et al., 2016)? In answering this question, even a selective consideration of geomorphic environments would pose related theoretical and methodological challenges, namely defining what we mean by human dominance in geomorphology (sensu Crutzen, 2002) and then measuring the relative geomorphic role of humans in recent Earth history. Addressing such challenges, however, is central to defining a role for geomorphology in debates over the credibility and practicality of recognising the Anthropocene as a new interval of geological time.

The Anthropocene debate contains strong elements of a human-nature dichotomy. The idea of demarcating an interval of geological time - of whatever rank (e.g. Era, Period, Epoch, Stage) during which human actions have been dominant, implies that in earlier intervals Earth surface processes can be seen as 'natural' with little or no human impact. This human-nature dichotomy has been questioned, both in the social and physical sciences (Rhoads and Thorn, 1996), but what is not disputed is that first-order processes that underlie geomorphology are external to human actions (Church, 2010). In short, humans operate within the laws of physics, from which fundamental geological principles are derived (e.g. superposition, isostasy). Nonetheless, human activities (e.g. mountain top removal, reservoir construction) can significantly affect the operation of some fundamental autogenic geological processes (e.g. neotectonic movements and seismic activity). More commonly, human activities alter the boundary conditions of second-order (or mixed) processes (e.g. sediment erosion, transport and deposition). This impacts on the trajectories and rates of process-response systems through effects on connectivity, inequality and thresholds (tipping points, nonlinearity) of matter and energy fluxes (Haff, 2010; Wainwright et al., 2011; Wohl, 2013).

Against this background, this paper has five main aims. First, we describe approaches to defining 'dominant' or 'overwhelming' human impact. Second, we sample geomorphological studies across four key second-order process domains (aeolian, fluvial, cryospheric, coastal) to address the nature, magnitude, diachrony, longevity and preservability of human impacts on landforms, sediments and stratigraphy. Third, we consider a selection of anthropogenic landforms, namely those created as a direct and commonly deliberate result of human activities. Fourth, we address the contribution of geomorphology to stratigraphic debates about an Anthropocene. Finally, we draw attention to other geomorphologically-relevant topics that have emerged during the Anthropocene debate, including the reciprocal effect of anthropogenic landforms on second-order processes, and the implications for differentiating between human and natural forcing. Many of these topics have not yet been regarded as high priority by the geomorphological or wider geoscience community but arguably are going to be of increasing importance in future. 


\section{Defining Dominant or Overwhelming Impact}

The formal recognition of the Anthropocene is contingent on being able to identify an undisputed dominant, or overwhelming, impact of human actions on second order processes. This requires a workable distinction between human and non-human process or mass transport dominance. For geomorphology, 'dominant' must imply humans are the most influential driving factors (over $50 \%$ outcome determination), whereas 'overwhelming' might be considered as higher (at least 95\% outcome determination). In practice, this distinction has always been difficult to establish, and in many instances may be impossible. One approach is to concentrate on humans as stressors, which in essence is what the global atmospheric modification argument is predicated upon (Hulme, 2009). This is more difficult in geomorphology, although attempts have been made using global estimates of surface mass action (Haff, 2010). Although this approach has limitations, such as having no boundaries with socio-economic systems (e.g. oil transportation) and not necessarily being related to geomorphological features, it can indicate process dominance in key sub-systems, the most obvious of which is soil ( $c f$. the critical zone). If we make the reasonable assumption that in all soils under cultivation, bioturbation is dominated by direct human actions (e.g. through tillage), and that in pasture lands bioturbation is indirectly influenced by human actions (e.g. through grazing practices, use of fertilizers, and associated changes in soil fauna), then we can estimate the minimum area of the Earth's land surface where human activity dominates soil processes. Using world agricultural land estimates, this would give human dominance over at least $38 \%$ of the Earth's ice-free terrestrial surface. In urban areas, bioturbation is suppressed by human activity, so the total figure rises to $45 \%$ of the ice-free terrestrial surface (Hooke, 2012). Based on similar estimates, several geomorphologists have tried to compute anthropogenic soil transport rates by taking the difference between natural (i.e. geological) and agricultural estimates of soil erosion rates (Hooke, 2000; B. Wilkinson, 2005; Montgomery, 2007). Whilst this latter approach is the most obvious for quantitative partitioning of natural and human contributions to erosion and sediment transport, it requires comparative data and involves several assumptions. Several methods have been used to estimate natural rates (Table 1) and all have their limitations, so that even for climaticallycomparable areas, calculated rates vary by at least one order of magnitude. This variability is because the range of methods used to calculate rates typically do not measure the same 'events'; for instance, denudation rate estimates from a long-lived cosmogenic isotope are significantly different in both temporal and spatial scale from erosion rate estimates made from naturally vegetated plots on a slope. Furthermore, 'within method' estimates also vary considerably due to differences in soils and vegetation (Kosmas et al., 1996; Wainwright and Thornes, 2004). For example, even the estimates derived just from cosmogenic isotopes used by Montgomery (2007) vary by over one order of magnitude (0.001-0.034 mm yr $\mathrm{m}^{-1}$ ), and as more basin-outlet studies have been undertaken, this variance has increased (Brown, 2016).

There is also an embedded assumption of equilibrium with climate, an assumption that is increasingly being questioned and that in many ways is at odds with the nature of geomorphology in the putative Anthropocene (Bracken and Wainwright, 2006; Hoffmann et al., 2010). Below, we consider the case for an Anthropocene in more detail for various process domains.

\section{Second-Order Process Domains}

We have divided the terrestrial Earth system into aeolian, fluvial, cryospheric and coastal domains in order to examine human impacts at the second-order level. This division does not imply that these are the only, or even the most, anthropogenically-sensitive process domains (others might include weathering, hillslope or karstic systems), only that they are major subdisciplines of geomorphological research. 


\section{Aeolian process domain}

Human activity primarily affects aeolian processes by directly or indirectly changing the erodibility of sediments that are suitable for wind transport or by altering aeolian sediment budgets. One of the most commonly cited causes of increased aeolian surface erodibility is vegetation cover reduction resulting from agricultural or pastoral activities. In China, these activities are widely cited as increasing dust flux (Li et al., 2009; Wang et al., 2013), with agricultural practices estimated to have increased wind erosion rates by two to five times background levels (Shia et al., 2004).

Nevertheless, the drylands that are most prone to anthropogenically-enhanced aeolian activity are also prone to marked climatic variability, which itself contributes to natural vegetation cover changes and to consequent temporal and spatial variations in aeolian activity. Remote sensing has been employed, however, to distinguish natural (climatically-induced) variability in bare surfaces in aeolian landscapes from those enhanced by agriculture, as the latter tend to persist through wetter years (Thomas and Leason, 2005). Remote sensing techniques can also be used to distinguish anthropogenic sources of dust (Hahnenberger and Nicoll, 2014).

It is also possible to monitor the impact of human activities on the morphology and dynamics of continental dune systems that are a legacy of periods of drier and windier conditions earlier in the Quaternary. Today, these dunes tend to be stabilised by vegetation cover but remain vulnerable to anthropogenic disturbances (Barchyn and Hugenholtz, 2013). Intermittent late Holocene dune mobilisation in the northwestern Negev Desert has been linked to various human activities that have reduced vegetation cover and disturbed biogenic soil crusts. The resulting increases in surface erodibility have triggered changes to dune morphology, including planform realignment and increased height (Tsoar and Møller, 1986). These changes have in turn facilitated short-term increases in wind power to trigger major dune mobilisation events (Roskin et al., 2013). There are also model-based analyses that hypothesise reactivation of presently stable dunefields under anthropogenically-influenced warmer future climates (Thomas et al., 2005; Ashkenazy et al., 2012). Even away from desert and semi-desert regions, there is evidence of past human activity affecting stabilised dunefields by changing vegetation cover; for example, Mauz et al. (2005) ascribed multiple late Holocene reactivations of dunefields in Schleswig-Holstein, Germany, to anthropogenic activity.

There are instances where aeolian activity can decrease when human activity reduces sediment supply. For instance, the connectivity between fluvial (supply) and aeolian (accumulation) sedimentary systems may be disrupted, as demonstrated by Draut (2012) in dunefields adjacent to the Colorado River, southwest USA. Here, dam construction has decoupled dunes from fluvial sand supply, resulting in dune surfaces developing biogenic soil crusts and greater biomass, and leading to less aeolian sand transport. The proportion of active aeolian sands is substantially lower in heavily regulated river reaches than in less regulated reaches with otherwise similar environmental conditions (Draut, 2012).

Widespread human modification of the aeolian process domain does not necessarily mean that anthropogenic signatures can be identifed in aeolian landforms and sedimentary records, as resultant sedimentary units are rarely distinguishable from their natural counterparts, and may be very dispersed in the landscape. Nevertheless, anthropogenically-enhanced aeolian activity has been proposed as an explanation for step-changes in dust deposition rates recorded in marine, ice, lake and peat cores, including in Greenland (Sandgren and Fredskild, 1991), USA (Neff et al., 2008), off the coast of north Africa (Mulitza et al., 2010), Australia (Marx et al., 2014) and Antarctica (McConnell et al., 2007). The timing of increased deposition rates varies in association with the spatially-specific human causation. For example, Atlantic marine core records suggest wind erosion in the Sahel increased fivefold since the onset of agricultural irrigation in the 1700s (Mulitza et al., 2010) but in southwestern Colorado, USA, lacustrine dust deposition increases from $<150 \mathrm{~g} \mathrm{~m}^{-2} \mathrm{yr}^{-1}$ to $>400 \mathrm{~g} \mathrm{~m}^{-2} \mathrm{yr}^{-1}$ are attributed as a response to the expansion of livestock grazing in the mid $1800 \mathrm{~s}$ (Neff et al., 2008). In some instances, local, 'on site' aeolian deposition is attributed to human disturbance. In the Free State, South Africa, unconformable sand cappings on stable dunes, field- 
boundary dunes and buried boundary fences have been associated with the establishment of permanent farm units by European farmers in the 1880s (Holmes et al., 2012).

In some regions, anthropogenic impacts on aeolian processes are now being reduced. In Australia, soil conservation measures have reduced dust deposition rates to pre-anthropogenic levels (Marx et al., 2014; Figure 1). However, the failure of the (probably over-) ambitious Green Dam project in Algeria (Ballais, 1994), which involved large scale afforestation of landscapes vulnerable to aeolian erosion, highlights our lack of skill in attempting to control aeolian processes (Benazzouz and Boureboune, 2009). More promisingly, systematic monitoring of aeolian dynamics in agricultural fields in South Africa has led to simple changes in agricultural practices being proposed that could significantly reduce wind erosion (Wiggs and Holmes, 2011) although modelled predictions of future changes in wind power and moisture availability may more than negate the benefits of such action. Given the unconstrained nature of aeolian sediment movement when compared to fluvial systems, and the complex, sometimes nonlinear, interactions between atmospheric and surface parameters that generate or limit aeolian processes, identifying anthropogenic impacts on aeolian landforms and sediments remains challenging.

\section{Fluvial process domain}

Human activity can influence fluvial processes indirectly through land-use changes that modify flow discharge, sediment loads and river system connectivity (Notebaert et al., 2011; Fryirs, 2013) or directly through mining activities and various forms of river management (Hudson et al., 2008). The latter include within-channel constructions (e.g. dams, weirs) that modify river long profiles and create anthropogenic sediment sinks (Syvitski et al., 2005; Walter and Merritts, 2008) as well as floodplain structures (e.g. levées) that impede channel-floodplain connectivity (Hudson et al., 2008). Since Leopold and Miller (1954) outlined palaeohydrological research as a means of elucidating human agency in soil erosion problems, various approaches have been employed to quantify the magnitude, patterns, rates and timing of anthropogenic changes to the fluvial process domain (Thorndycraft, 2013). Approaches include: i) documenting changes to spatial patterns and rates of key fluvial processes such as avulsion (Tooth et al., 2009); ii) identifying and dating stratigraphic markers of human impact, such as sedimentological changes in floodplains (Walter and Merritts, 2008) or lakes (Dearing and Jones, 2003), the presence of inter-stratified cultural material (Brown, 1997), mineral or element changes (Hudson-Edwards et al., 1999), and palaeoecological biostratigraphic markers (e.g. Brown, 1988); iii) quantifying long-term sediment fluxes through sediment budget approaches (Brown et al., 2009), cosmogenic nuclide studies (Wittmann et al., 2011), or global scale models (Syvitski et al., 2005); and iv) modelling catchment scale river response using landscape evolution (e.g. Coulthard and Van De Wiel, 2012) or hydrological models (e.g. Notebaert et al., 2011).

These approaches show that human impacts may either increase or decrease fluvial activity. Globally, however, some floodplains possess stratigraphic units attributable to anthropogenicallyenhanced soil erosion, principally overbank loams that host archaeological remains (Brown, 1997) (Figure 2). A similar anthropogenic stratigraphy may also be recorded in lake sediment archives (Dearing and Jones, 2003), possibly in association with anthropogenic geochemical (Boyle et al., 2015a) or even DNA signatures (Taberlet et al., 2007). In extensively studied regions such as northwest Europe, the Mediterranean and North America, such floodplain and lake stratigraphic markers are diachronous, the timing of anthropogenic increases in soil erosion being dependent on the regional history of deforestation and agriculture. In addition, human impact on floodplain ecosystems can be reconstructed using palaeoecological evidence from alluvial peats (Brayshay and Dinnin, 1999). For example, many pollen stratigraphies reveal anthropogenic deforestation signals, again showing diachronous timing of human impact, even within the same river catchment (Brown, 1988).

Considering human impact on fluvial activity at the global scale, Syvitski et al. (2003) outlined a relief-area-temperature model to predict sediment flux to oceans. For $75 \%$ of 320 river 
catchments, modelled fluxes were within a factor of two of the observed data. Modelled fluxes, however, were overestimated where major reservoir storage reduced sediment loads (e.g. Tagus River, Portugal) and underestimated in some areas of anthropogenic soil erosion (e.g. Huang River, China), most commonly in smaller catchments where the anthropogenic impact was magnified. Applying the model to 4464 river catchments across the globe with drainage areas $>100 \mathrm{~km}^{2}$, it was found that the net balance was a $1.4 \mathrm{Bt} \mathrm{yr}^{-1}$ reduction in sediment flux to the oceans due to reservoir sediment retention, despite increased anthropogenic soil erosion (Syvitski et al., 2005). By simplifying processes to enable global scale modelling, however, such approaches may not accurately represent the role of sediment storage. Using digital topographic data and an empirical volume-area scaling of valley fills, Blöthe and Korup (2013) quantified the sediment stored in over 38 000 Himalayan valley fills, and found millennial-scale time lags in the sediment routing systems of the Brahmaputra and Ganges, rivers that deliver $\sim 10^{3} \mathrm{Mt} \mathrm{yr}^{-1}$ to the ocean. Such storage can complicate the attribution of climate or seismic controls to sedimentary records (Blöthe and Korup, 2013) and, by extension, the attribution of human activity. Based on cosmogenic nuclide-derived sediment fluxes, a sediment storage buffering capacity has also been noted in the Amazon basin (Wittmann et al., 2011). Sediment production in the Andes was the same as the sediment delivery to the ocean, suggesting little change in sediment flux over recent millennia and implying that potential human impact on this flux was limited due to the large scale of the Amazon system (Wittmann et al., 2011).

Some studies have focused more explicitly on the profound, often highly visible, changes to fluvial process and form resulting from mining. Mining may involve many catchment hydrological and sediment supply changes as a consequence of deforestation, road construction, and river diversion (Mossa and James, 2013). Ever since Gilbert's (1917) pioneering studies, geomorphologists have used mining-impacted rivers as an outdoor laboratory for studying the major, commonly abrupt, changes to channel form resulting from sediment supply increases, including in California (James, 2004, 2005, 2013; Singer et al., 2013) and Australia (Knighton, 1989, Pickup et al., 1987; Erskine and Saynor, 2000). Lakes within fluvial catchments affected by mining also may preserve evidence of increases in sediment flux and contaminant delivery (Boyle et al., 2015b). A range of other human activities such as irrigation and navigation also can result in profound changes to fluvial processes and forms, particularly through radically altering channel-floodplain connectivity. For example, in a multi-faceted review, Lewin (2013) showed how many British floodplains have been genetically transformed through four phases of human activity over the last 400 years.

From these case studies, it is clear that, with the exception of heavily-modified catchments, the relative magnitude of human impact on the fluvial process domain is dependent on catchment scale, tectonic activity and relief, and susceptibility to erosion. The anthropogenic signal may be more clearly defined in small- to medium-sized catchments draining, for example, highly erodible loessic landscapes (e.g. Notebaert et al., 2011). The signal may be less clear in large catchments such as the Ganges and Brahmaputra that are subject to active tectonic activity and high sediment supply, and characterised by accommodation space for medium term sediment storage, subsequent erosion of which can nourish sediment flux for millennia (Blöthe and Korup, 2013). The complexities of the processing of human impacts through the fluvial system to alluvial sedimentary records are illustrated in Figure 3 and it is this complexity that renders simplistic approaches to human attribution (e.g. sediment delivery ratio) as unreliable (Parsons et al., 2006a). While human activity can be seen to influence all four areas of the fluvial system (Figure 3), the magnitude, patterns, timing and rates of these impacts and the recognition of anthropogenic markers in landforms and sediments are dependent on catchment characteristics and exhibit large spatial and temporal variability.

This article is protected by copyright. All rights reserved. 


\section{Cryospheric process domain}

At a global scale, net loss of ice is already happening (Vaughan et al., 2013) and is highly likely to continue in a warming world (Kirtman et al., 2013). Ice sheets, glaciers and permafrost respond principally to climate, but given the now well-established anthropogenic influence on global warming, this cryospheric response potentially might be regarded as a global-scale manifestation of an Anthropocene.

The majority of the world's monitored glaciers have retreated and lost mass during the 20th Century, with deglaciation increasing since the 1960s (WGMS, 2008; Vaughan et al., 2013). The geomorphological imprint of such rapid deglaciation includes both near-field and far-field effects. In ice-proximal settings, ice-marginal retreat and declining ice volume lead to exposure of new terrain and extension of proglacial systems (Evans, 2003), thereby encompassing a variety of landforms and sediments. There are also associated changes in paraglacial processes (Ballantyne, 2002). Farther afield, there are changes to river hydrology, and implications for the coastal zone in terms of changing sediment supply and sea level rise (WGMS, 2008).

Deperiglaciation is also significantly affecting many areas rich in ground ice (permafrost). In high latitudes, thawing of permafrost (thermokarst) can be initiated, retarded or counteracted by numerous factors operating on local to regional scales: from local damage to the vegetation or organic layer, to regional increases in snow cover or mean annual temperature (Table 2). Human activities can affect these factors, both directly and indirectly, but can be hard to separate from natural drivers. For instance, disturbances that initiate thermokarst activity are often compound and interactive, such as where a boreal forest fire - either natural wildfire or anthropogenic fire initiates active layer deepening and thermokarst subsidence by destroying the shading effect of the vegetation canopy, reducing heat loss from evapotranspiration, and lowering surface albedo (Kokelj and Jorgensen, 2013). There is clear evidence that thermokarst activity during the last 100-150 years has spread and intensified as result of multiple causes (Murton, 2009) but if global warming continues, thermokarst activity is likely to intensify and spread farther during this century (e.g. see projections of future permafrost extent in Vaughan et al., 2011; Lawrence et al., 2012; Koven et al., 2013). In lower latitude but mountainous regions, there is also evidence of recent increased periglacial activity. As ground ice warms, it softens, accelerating creep in rock glaciers and talus, and weakening ice-filled joints in rockwalls (Davies et al., 2001; Haeberli et al., 2010). Potentially, this can destabilise rock slopes and enhance mass movement (Krautblatter et al., 2013).

Viewed in the context of Quaternary ice extent, however, recent rapid deglaciation and deperiglaciation are not unprecedented. For instance, rapid and widespread deglaciation occurred at the end of every previous glacial, and although ice extents are difficult to gauge during previous warm intervals in the Holocene, in parts of the world (e.g. Alps, Scandinavia, Altai) there is evidence for more restricted ice extent than at present (Masson-Delmotte et al., 2013). Similarly, while the strongest manifestation of thermokarst activity in the geological record is from the last glacialinterglacial transition and from the penultimate interglacial (Murton, 2009; Reyes et al., 2012), comparison of natural activity rates with recent anthropogenically-influenced rates is extremely difficult. Furthermore, it remains difficult to discern a landform or sediment signature uniquely attributable to anthropogenically-influenced cryospheric change. Hence, despite the clear evidence for the contribution of human activities to recent deglaciation and deperiglaciation, it seems premature to identify an Anthropocene from landforms or sediments in the cryospheric process domain.

\section{Coastal process domain}

Human impact on the coast is arguably more pronounced than for any other part of the Earth system. A significant proportion of the world's population lives in coastal lowlands (e.g. Small and Nicholls, 2003) and this population is growing, especially in the world's megacities (Sekovski et al., 2012). Consequently, the coastal process domain is increasingly impacted, both directly and indirectly. River catchment developments (e.g. reservoir construction) may reduce coastal sediment 
supply (Syvitski et al., 2005), and coastal engineering and management interventions (e.g. groynes, harbour walls, navigation structures, storm surge barriers, dredging, recharge and reclamation) exert considerable control over coastal hydrodynamics and, hence, sediment transport. For instance, maintenance dredging for safe navigation is often required to remove sediment from channels that would not otherwise be flushed naturally, and locally increases the net sediment budget and accretion rates (e.g. Blott et al., 2006). Indeed, manipulation of hydrodynamics and sediment flux is an underpinning principle of both 'hard' and 'soft' engineering approaches but commonly has led to 'down coast' or 'downdrift' problems as humans have been, in essence, interfering with the natural redistribution of a limited sediment budget (Bruun, 1995). This human influence has controlled the existence of thresholds, creating geomorphic coastal regime shifts since the mid to late Holocene (e.g. Beets and van der Spek, 2000; Cooper et al., 2007; Blum and Roberts, 2009) such as where sediment starvation has led to reduced progradation and coastal erosion (e.g. Nile delta: Fornos, 1995). Recently, human intervention has tended to move from hard to soft engineering, which may involve augmenting and maintaining coastal sediment supply (dredging and beach recharge). In recent years, monitoring of coastal erosion has undergone a revolution owing to the availability of high speed high-resolution terrestrial laser scanning (TLS) that is capable of recording cliff faces at $\mathrm{mm}$ spacing at over 1 million points per second. TLS has recently been used in a study of cliff erosion rates in Druridge Bay, northeast England (Figure 4), where archaeological heritage is being lost due to a combination of natural change and sediment starvation caused by erosion protection elsewhere along this coast (Lobb and Brown in press).

Anthropogenic modification of shorelines, either deliberate or otherwise, has a long history. Some large delta systems have been able to keep pace (or even exceed) regional sea-level rise and coastal subsidence through changes to fluvial sediment supply (Syvitski et al., 1988; Saito et al., 2001). Probably the best example is the Ebro delta, Spain, which did not exist prior to the Roman period, and so is the creation of a late Holocene, anthropogenically accelerated sediment supply (Xing et al., 2014). Past manipulation of tidal inundation and sedimentation has included intertidal wetland 'reclamation' and 'warping' as well as the Terpen mounds in Zeeland and Friesland, where mounds were artificially created to provide flood protection in inhabited coastal lowlands (Charlier et al., 2005). These human interventions differ from the more widespread activity of reclamation (land claim cf. Allen, 1987), which involves preventing marine inundation of tidal wetlands by construction of embankments, then enabling dewatering and desalinisation of the soil for the creation of highly productive lowland agriculture (e.g. the English Fenland or Dutch Zuiderzee). In recent decades, large scale shoreline modifications have led to the emergence of entirely new anthropogenic coastal landforms (e.g. Palm Islands, Dubai; Kansai Airport, Japan).

The sedimentary consequences of these anthropogenic modifications are manifold. Coastal reclamation includes artificial fill of low-lying land, leading to anthropogenic deposits ('made ground') that overlie natural Holocene sediments (Jordan et al., 2016). In the Dee estuary, UK, navigation works at the head of the estuary caused rapid salt-marsh accretion along the English shore, replacing the low-water tidal channel and beach (Marker, 1967). Also, there is the 'unseen' legacy of human activities in the form of pre-historical and historical pollution, which can be used to reconstruct the diachronous impact of human activities on the world's coastlines. Much pollution is linked to ore mining and metal production in river catchments (e.g. Allen and Rae, 1986), but coasts also have been the main locations for metal and chemical industries (e.g. Plater and Appleby, 2004). In Europe, many salt-marsh sediments preserve a record of pollution from the Bronze Age, through the Roman and Medieval periods, to the more recent industrial era (e.g. Haslett et al., 1998; Plater et al., 1998; Davis et al., 2000; Alfonso et al., 2001; Carretero et al., 2011). Heavy metals, for instance, have been used to define a late Holocene stratigraphy in estuaries such as the River Severn, UK (Allen, 1987; Allen and Haslett, 2014). In other locations, pollen can record catchment land-use changes. In the US, for example, 'exotic' taxa in estuarine and lagoonal sediments can be linked to ranching, agriculture and logging arising from Mexican and European immigration (Mudie and Byrne, 1980; Brush, 1989). 
Against the backdrop of dramatic eustatic sea level variations during the Quaternary but relative stability over the last $8 \mathrm{ka}$, human activity in the coastal process domain can be characterised as changing from process manipulation and consequential (often unintended) changes in coastal geomorphology to more direct shaping of coastal sediments and landforms. Many human activities have had a detrimental impact on coastal geomorphology, in some cases leading to significant shoreline degradation. This has worked against actions to artificially supplement coastal sediment supply through dredging and beach recharge, without which coastlines would experience wider sediment starvation. This does not bode well for future coastal developments, unless there is a managed transition to coastal ecosystems that are better suited to low sediment input and high rates of relative sea-level rise (e.g. perimarine wetlands; Plater and Kirby, 2006). For example, in the UK, there are currently several major managed re-alignment schemes that involve the deliberate breaching of sea defences to flood areas of coastal lowlands (e.g. Steart Peninsula, southwest England, and Medmery, southern England). In other cases, if present barriers were to be breached, they would probably not be re-built, such as was the case at Porlock, southwest England, in 1996 (Jennings et al., 1998).

In the coastal process domain, the interactions between natural controls, as exemplified by El Niño/La Niño dynamics, and human influences remain poorly understood but are critical to the understanding and management of landform dynamics. Nonetheless, the foregoing case studies demonstrate that an anthropogenic signature can be found in landforms and sediments along many coastlines worldwide.

\section{Anthropogenic Landforms}

Geomorphologists have long recognised the profound human influences on Earth surface processes and landforms caused by activities such as mining (e.g. Gilbert, 1917) and urbanisation (e.g.

Wolman, 1967). Until relatively recently, however, the quantification and characterisation of human agency in geomorphology tended to focus on the identification of impacts of land use change, the global differentiation of sediment transfer masses and rates, and engineered environments.

Following the 'Great Acceleration' (post-World War II), the rapid spread of mechanised agriculture, extractive industries and urbanisation has resulted in an increase in the abundance and prominence of anthropogenic landforms, namely those created as a direct and commonly deliberate result of human activities (e.g. Szabó et al., 2010). In some extensively farmed, mined or urbanised areas, the scale of human modification is now so great that anthropogenic landforms provide the main Earth surface boundary conditions for geomorphic processes (Foley et al., 2005; Ellis, 2011; Tarolli et al., 2014, 2015; Tarolli and Sofia, 2016). To illustrate our case, below we provide selective coverage of a range of anthropogenic landforms, including slopes, road networks, heavily modified drainage networks and mining-related features.

\section{Artificial slopes and other landforms}

Some of the most prominent anthropogenic landforms are agricultural terraces (Tarolli et al., 2014). Modification of slopes to form terraces had its origins in early agriculture in southwest Asia, northern China and Korea, and the practice later spread farther afield. In parts of southwest Asia, such as the Yemen, agricultural terracing is thought to date to the Neolithic (c. 3500 BC) while in much of the Mediterranean and northwest Europe, terraces date to the Bronze and Iron Ages (c. 3000-0 BC) (T. Wilkinson, 2005; Walsh, 2014). By reducing slope gradient, terraces facilitate cultivation on steep slopes, increase infiltration, and control overland flow volumes and velocity. Archaeological or historical terraces are generally of the bench (or fast) type with stone walls that require maintenance, so poorly designed or maintained terraces can enhance soil erosion rates, while well designed and maintained systems can reduce erosion rates (Tarolli et al., 2015). Consequently, once constructed, terraces document social history, in particular rural population densities, and influence soil erosion and land degradation. Geomorphologists are now making considerable advances in the automated detection of agricultural terraces from LiDAR and other 
forms of remote sensing (Sofia et al., 2014a; Tarolli et al., 2014) and this will feed into distributed basin models for water, sediment and pollutants. Sofia et al. (2014b) showed that natural slopes are more variable and less correlated, while artificially modified slopes with terraces have a high level of self-similarity. These differences can be statistically and automatically distinguished using a new topographic indicator termed Slope Local Length of Auto-Correlation (SLLAC) (Figure 5).

Other major anthropogenic slope forms include cuttings and embankments for railways, roads, canals and irrigation networks (Tarolli et al., 2013; Sofia et al., 2014a, 2014c). Since these forms are almost universally rectilinear and fall within a narrow range of gradients, particularly for embankments $\left(26-32^{\circ}\right)$, this introduces a systematic element into regional slope-area relationships. Although fundamentally engineering structures, studies of their stability and sustainability have owed much to geomorphologists (Fookes et al., 2009). Geomorphological processes on engineered slopes will continue to be important in future, as unpaved roads ('dirt tracks') in the developing world are upgraded and metalled, invariably being associated with large areas of artificial slope that need to remain stable under changing climatic conditions. These new and expanded road networks, artificial slopes, and their related drainage systems will affect surface morphology, change local flow directions, and possibly increase soil erosion or landslide risk.

Urban development is also commonly associated with significant anthropogenic landforms (Thornbush, 2015). At least $741630 \mathrm{~km}^{2}(0.5 \%)$ of the Earth's terrestrial area is now urbanised (Schneider et al., 2009), in most cases leading to widespread removal of natural vegetation, creation of entirely artificial surfaces, and heavily modified drainage systems, as epitomised by Manhattan Island, USA (Figure 6). Urban drainage systems in particular exemplify many anthropogenic landforms (e.g. heavily channelised rivers, artificial flood basins, and sewerage systems) and have been the focus of much research (e.g. Chin, 2006; Chin et al., 2013; Gurnell et al., 2007).

Many other large-scale examples of anthropogenic landforms can be found, especially in China. The largest ever human refashioning of the landscape is currently taking place in central China (Lanzhou) where 700 mountains are being levelled to create more than $250 \mathrm{~km}^{2}$ of flatter land. This is causing a host of geomorphic problems including subsidence, landslides, flooding and air pollution (Li et al., 2014). China is also undertaking large-scale land reclamation (island building) around atolls, reefs and sand bars in the South China Sea, with unknown implications for sediment dynamics and island stability.

There are also many medium- to small-scale landforms that appear to be entirely the result of human activity. Examples include 'roddons' - low raised palaeochannel infills that cross temperate wetlands - that are the result of artificial drainage and shrinkage of these lowlands (Brown, 1997). More diminutive human-influenced landforms include grazing steps, vehicle ruts and footpaths (Garland, 1990) but in most cases, these landforms do not have uniquely anthropogenic morphometric signatures and commonly are identified indirectly by vegetation change. Even human conflict has left a significant geomorphological signature through the construction of trenches and earthen banks, and the formation of bomb craters and vehicle tracks (Hupy and Koehler, 2012).

\section{Holes in and under the ground}

Holes in the ground (e.g. from quarrying and opencast mining activities) are morphologically different from natural landforms (Figure 7A) and will have longevity into the future, either in surface expression and/or stratigraphy (Zalasiewicz et al., 2011). In some cases, the spoil from these activities can also lead to the creation of distinctive landforms, such as the conical piles of china clay mining waste that have given rise to the 'Cornish Alps' near St Austell, southwest England, or the flat-topped and terraced gold mining dumps around Johannesburg, South Africa (Figure 7B). In developed economies, especially densely populated countries, the extent of anthropogenic landform creation through quarrying and mining is substantial, although as yet not fully quantified.

Nonetheless, besides the impact on fluvial and coastal processes (see above), mining has become a focus of research because of its implications for geomorphic hazards (Mossa and James, 2013; Tarolli and Sofia, 2016). Open-cast mining, for instance, causes severe land disturbance that affects 
vegetation, soil, bedrock and landforms (Martín-Duque et al., 2010) as well as surface hydrology, groundwater levels and flow paths (Osterkamp and Joseph, 2000; Nicolau and Asensio, 2000). Together with climate (Erginal et al., 2008) and geology (Laimer and Mulleger, 2012), mining morphology can contribute significantly to landsliding susceptibility.

These and other examples of mining-related activities demonstrate that along with the creation of agricultural terraces, embankments and cuttings (see above), the volumes of rock/earth moving by human action can be considerable. For instance, in the UK, Price et al. (2011) have estimated that over the last 200 years people have excavated, moved and constructed a volume of soil and rock at least six times the volume of Ben Nevis, Scotland's tallest mountain. Artificial or 'worked' ground has long been a category on geological maps but it is now categorised into a series of 'domains' at 1:50 000 by the British Geological Survey (Figure 8). The practical reason for undertaking this exercise is to allow estimation of potential threats of instability or pollution under changing climatic conditions.

\section{Geomorphology and Stratigraphy}

Stratigraphic status, whether formal or informal, garners much attention in geological science. As pointed out by Gibbard and Walker (2014, p.30), stratigraphy "is the foundation upon which the discipline of historical geology, and therefore the accurate reconstruction of Earth history, depends." Stratigraphic status gives a level of authority to an assemblage of rocks, landforms, biota or chemistry and to the period of time involved, yet tends to provoke emotional judgements and generate contentious debate, as seen with the recent re-definition of the base of the Quaternary and Pleistocene (Gibbard et al., 2009 and references therein). A number of recent papers and volumes have been concerned specifically with the stratigraphic basis of an Anthropocene (e.g. Finney, 2014; Gibbard and Walker, 2014; Waters et al., 2014a, b; Zalasiewicz et al., 2011, 2014). Here, we seek to identify the geomorphological contribution to the debate. Four issues are considered: i) geomorphological evidence as a stratigraphic method and the source of stratigraphic units (morphostratigraphy) in a putative Anthropocene; ii) geomorphological processes as key drivers for the formation of sediments, biota and chemical compounds that constitute the materials of an Anthropocene chronostratigraphy; iii) a geomorphological perspective on the timing of the onset of an Anthropocene; and iv) alternative stratigraphic schemes.

\section{Geomorphology, morphostratigraphy and an Anthropocene}

By definition, stratigraphical criteria based on geomorphological features are morphostratigraphical, which means that landform shape provides the critical evidence. This is the case, for instance, with features such as displaced shorelines, moraine ridges, or river terraces that represent land-forming events over a given time interval (Frye and Willman, 1962; Allen, 2003; Lukas, 2006). With respect to an Anthropocene morphostratigraphy, this should mean that human processes are involved in the formation of a given landform, and that the human influence should be recognisable from the shape of that landform. Again, by definition, this should mean that landforms composed of made-ground or spoil, or that are specifically created (e.g. embankments, artificial levées, agricultural terraces and even ski-slopes) are anthropogenic morphostratigraphic units (Price et al., 2011; Ford et al., 2014). Likewise, depositional landforms built to imitate natural features for restoration, aesthetic planning or recreation purposes (e.g. hills, man-made pleasure beaches) are anthropogenic morphostratigraphic units, although they may be more difficult to differentiate from natural features (see below). Nonetheless, it may be possible to use anthropogenic morphostratigraphy to determine particular periods of time. For instance, English ridge and furrow are typically medieval (5th to 17th Century), although some were formed during 20th Century wars (Mead, 1954). In other parts of the world, as noted above, agricultural terraces define particular periods of landscape change (Hooke, 2006; Chepstow-Lusty et al., 2009). Documentation associated with industrial spoil heaps, quarries, open cast mines and strip mining also can provide an age for the morphostratigraphical features (Ford et al., 2014). The application of this principle is almost infinite, 
with a temporal resolution determined by the quality of the historical, archaeological or geochronometric dating.

Morphostratigraphy is clearly critical in making the case for an Anthropocene, as these landforms are unique to a human-influenced geological time interval. However, evidence of human activity is not restricted to landforms but also affects the constituents of sediments and rock that make up landforms, as these also may contain traces of anthropogenic input (e.g. 'plastiglomerate' now forming on certain Hawaiian beaches: Corcoran et al., 2014). In these cases, which are perhaps best approached through the perspectives of sedimentology, biology, meteorology or chemistry, the geomorphological contribution will be to clarify how geomorphic processes help to determine the end product: the polluted sediments, exotic plant or animal characteristics, and the anomalous atmospheric chemical compounds. An array of these highly diachronic anthropogenic signatures from megafaunal extinctions to radionuclides is listed in Waters et al. (2014b).

\section{Geomorphological processes, chronostratigraphic evidence and an Anthropocene}

From the foregoing, it is evident that understanding of an Anthropocene relies on the processes that act at the Earth's surface. Geomorphological processes are critical because they are responsible for landscape erosion and material transport to sediment sinks. Whereas the link between morphostratigraphy and an Anthropocene through identification of diagnostic landforms is straightforward, at least in principle, the proposition that geomorphology is key for investigating human-induced Earth surface changes may not be so clear, as many landforms are not diagnostic of human activity, and other evidence is needed to recognise the human impact. For instance, a river floodplain or delta, formed in response to human activity, may be morphologically similar to a floodplain formed without human influences, but may be clearly differentiated by sedimentology, or by lithological and biological evidence contained within the sediments comprising the landform (Evans, 2012; Brown et al., 2013b). Similarly, aeolian dunes, formed in response to vegetation clearance for agriculture may be morphologically indistinguishable from dunes formed without human influence, so differentiation requires evidence from geochronology and/or historical records (Bateman and Godby, 2004). To identify human impact in these cases, a multi-proxy approach to stratigraphy is necessary, for where a number of proxies coincide, the more credible is the stratigraphic outcome.

Human-driven or human-influenced geomorphological processes bring about the series that constitute the chronostratigraphy (Salvador, 1994; Zalasiewicz et al., 2014). Along with the morphostratigraphic units, they would make the Anthropogenic Series of an Anthropogenic Epoch. As such, they are similar to stratigraphic units from other parts of the geological column, and are very similar to the stratigraphic elements that underpin Quaternary stratigraphy. Attention has been given, however, to their limited potential for survival and thus for becoming a significant part of a long-term geological record (see Waters et al., 2014b). This concern can be addressed by noting that similar evidence, formed by geomorphological processes at the Earth's surface, has survived throughout the geological column, albeit less frequently than ocean or basin sediments. Attention is also drawn to the fact that these series are the basis for the classification of the Holocene as a separate epoch, despite that fact that this time interval is simply the last of many interglacials in the Quaternary Period (Gibbard and Walker, 2014). This is a semantic issue and not the concern of geomorphology; the critical fact is that human-driven or human-influenced geomorphological processes determine an Anthropocene. These processes form a definitive part of the Holocene, although they are independent of the currently proposed subdivisions thereof (Walker et al., 2012). Geomorphology therefore plays a major role in establishing the stratigraphic elements upon which an Anthropocene could be defined, both now and in a long-term stratigraphic record. 


\section{Anthropogenic geomorphological processes and the lower boundary of an Anthropocene}

The location of a lower boundary for an Anthropocene has concerned many (e.g. Zalasiewicz et al., 2011, 2014; Gibbard and Walker, 2014, and references therein). Lewis and Maslin (2015) discuss two possibilities in defining the lower stratigraphic boundary of the Anthropocene: i) earliest evidence for human-induced stratigraphy which would be of local or regional significance only; or ii) a more distinctive event that can be recognised globally. The magnitude of this problem can be seen by the fact that the time span over which humans began to influence the Earth's surface may be greater than the span of an Anthropocene interval, depending upon which definition of an Anthropocene is adopted. In a consideration of possible alternative boundaries, Lewis and Maslin (2015) have proposed AD 1610 based on the Orbis spike dip in $\mathrm{CO}_{2}$ observed in two core records from the Antarctic Ice Sheet, or AD 1964 based upon the bomb peak in ${ }^{14} \mathrm{C}$. However, as they admit, these are only two possible candidates out of a large number of possible dates varying from early in the Holocene to the radionuclide events in the 1960s. Some have argued we have yet to reach the boundary (Monastersky, 2015).

An attempt to resolve this issue has been proposed by Foley et al. (2013), with the proposition that the time identified by the presence of hominins and by local and regional evidence should be known as the Palaeoanthropocene, and the interval after the Industrial Revolution (c. post-AD 1780), when human-induced changes started to significantly influence global climate, should be the Anthropocene proper. Alternative views can also be found (e.g. Ruddiman, 2003). In some ways the proposition for a Palaeoanthropocene recognises the importance of human activities in forcing geomorphological processes (e.g. Neolithic farming) but it does not solve the problem of the diachroneity of the lower boundary and it subsumes archaeological chronology. All stratigraphic boundaries are arbitrary, and arrived at by consensus through an 'accepted' procedure (Finney,

2014; Gibbard et al., 2009) but as far as geomorphology is concerned this issue should not be important. The geomorphological concern should be with process per se, rather than the formalisation of stratigraphy. It should provide the science behind the stratigraphic decisions, which even with the clarity or lack of resolution associated with geological time are often highly contested and generally represent compromises between universality, visibility and signal clarity.

\section{Geomorphology and alternative stratigraphic schemes}

The formal division of geological time is the responsibility of the International Commission on Stratigraphy, which is a constituent group of the International Union of Geological Sciences (Salvador, 1994). Any stratigraphic considerations should refer to the procedures of this organisation, especially with reference to the delimitation of timescales, and it is through these procedures that stratigraphic schemes are given authority. However, time is not the only information provided by stratigraphy, and for many professions, such as engineering, utility operations, the aggregate industry or the planning, finance and legal sectors, other geological properties are more important, such as lithology and texture, shrinkage potential (Harrison et al., 2012), flood potential, groundwater recharge potential, and erodibility. In these cases, the stratigraphic scheme approved by the International Commission on Stratigraphy may not be the most appropriate. Consequently, other schemes have been proposed, concentrating on surface materials where the industrial and commercial interest is focused (Walton and Lee, 2001). Rose (2010) has proposed a scheme for temperate latitude regions, exemplified by the British Isles, in which the stratigraphy is determined by processes operating on the landscape, and has identified four major systems, of which one is Holocene and Human Activity (HHA). By definition, HHA incorporates anthropogenic processes and identifies their importance within the areas concerned. McMillan and Merritt (2012) provided a scheme, again appropriate for the Quaternary (and hence an Anthropocene), in which the lithological properties of surface rocks are given priority, with time taking a secondary role. As geomorphology determines the distribution of different lithologies, say through ice-flow direction or sediment transport in drainage networks, it is a prime factor in the differentiation of the various stratigraphic units, but human impact is not traditionally considered. Thus, when geological materials are defined in terms of functionality rather than age, 
geomorphology can be a prime factor in deriving a stratigraphic scheme and the consideration of anthropogenic processes may be obligatory.

\section{The Reciprocal Impact of Anthropogenic Landforms on Second-Order Geomorphic Processes}

As outlined in the foregoing sections, mass fluxes associated with anthropogenic landforms such as agricultural terraces and engineered slopes are a prime feature of the putative Anthropocene. Geomorphology and civil engineering have a long history of studying such landforms and fluxes, partly because they can be viewed as open-air laboratories where boundary conditions are more easily controlled or measured. Classic examples include studies of rill and gully erosion on mining spoil heaps (e.g. Nyssen and Vermeersch, 2010), water chemistry changes resulting from acid mine drainage (Pirrie et al., 1999) and the failure of engineered slopes (Hutchinson, 2001; Fookes et al., 2009).

As areal coverage of anthropogenic landforms increases (cf. 'made ground' - Figure 8 ), then these fluxes will become proportionately or even disproportionately important. A related, more geological, argument is one of persistence, namely that these landforms, mass fluxes and sedimentary products are not transient but will persist into the future, with potential to enter the geological record. This potential depends upon the tectonic and physiographic content and the nature of the associated processes. For example, in fluvial systems, preservation is determined by tectonic setting (uplift, subsidence) and the relative importance of aggradation, incision, lateral migration and avulsion (e.g. Lewin and Macklin, 2003) so preservation patterns vary geographically in response to local and regional factors. For the Frome catchment, southwest England, it has been estimated that anthropogenically-accelerated floodplain alluviation has been so great over the last 4 ka that it would take in the order of 20-30 ka to remove the alluvium at the current rate of fluvial erosion (Brown et al., 2013b), which might render it geologically persistent. A complication here is the length of the current interglacial: if Berger and Loutre (2002) are correct, the ultimate geological signature of the Anthropocene will be a delay in the timing (or even suppression) of the next glacial. This scenario would facilitate the preservation of most lowland anthropogenic fluvial sediments and would be by far the largest geomorphological and stratigraphic impact of humans. Such fluvial mass balance changes can also impact on other geomorphological process domains, especially at the coast (see above). A subtle and yet to be fully elaborated effect is that of changing the tidal reach of rivers through increasing channel confinement and reclaiming marginal saltmarshes; in effect, creating a pseudo-regressive boundary that is not related to relative sea level fall (Havelock, 2009) and that is the opposite of the sediment starvation effects mentioned above.

Globally and on a geological timescale, this question of reciprocity may have profound dimensions. The view that humans are now the dominant force in global environmental change has led some to argue that we are outside the geological timescale and that maybe the geological scale stops now (Finney, 2014). However, it is hard to reconcile this viewpoint with the continuation of fundamental geomorphic processes and landform development. Humans can drive geomorphic systems, the products of which will persist and affect the future. Geological processes driven by the Earth's internal dynamics will also continue (e.g. global tectonics), although even they may be sensitive to feedback processes of vegetation and soil that may be influenced by human activity (Herman et al., 2013). Nevertheless, although we will remain within the geological timescale, how we segment and classify that timescale may have to change, since we may now lie outside the past geological norms that formed the basis of international stratigraphic procedures as formalised by Hedberg (1976).

\section{Human Versus Nature in the Anthropocene}

Both the underlying rationale for the Anthropocene and its manifestation through Earth surface processes may have profound conceptual implications for geomorphology and the wider geosciences. For such disciplines, the climate system has tended to be viewed as driven naturally by energy from the sun and distributed naturally by the global atmospheric and oceanic systems, and

This article is protected by copyright. All rights reserved. 
for many researchers this is still the case. This assumption fed into the difficult, but possible, differentiation of human versus natural forcing factors on Earth surface systems. However, if the climate system is significantly influenced by human activities, even if this is to an unquantifiable extent, then it cannot be equated with natural forcing in geomorphology. Therefore, it follows that attempts to differentiate between human and natural forcing become intractable, so representing a spurious or a meaningless vestige of Cartesian dualism (Rhoads and Thorn, 1996). The most pertinent aspect of this discussion is what effect the formalisation of the Anthropocene could have on geomorphology as a discipline, as there is the distinct risk that it could require reconsideration of its uniformitarian underpinnings (cf. Knight and Harrison, 2014; Paul, 2014). It follows that geomorphology, by definition, should provide the authority and substance for morphostratigraphy, even if this is not divisible into human versus natural forcing.

This pragmatic approach is also required because the changes to aeolian, fluvial, cryospheric and coastal process domains resulting from human-modified sediment fluxes and energy distributions have also altered ecosystems and critical zone processes responsible for ecological integrity (sensu Graf, 2001), ecosystem service provision (Millennium Ecosystem Assessment, 2005) and sustainability (sensu Parrish et al., 2003). Perhaps the most obvious example is the vast literature on the effects of soil erosion on the spawning of salmonid fish (e.g. Lisle, 1989; Sear, 1993; Jensen et al., 2006). Less obvious examples are the effects of exotic riparian plants on bank stability (e.g. McCarthy et al., 2010), or the little-researched effect of solar panel arrays on soil erosion due to runoff redistribution.

\section{Conclusions}

From our review of four key process domains, it is clear that the relevance of the Anthropocene concept varies substantially between different branches of geomorphology. Fluvial and coastal geomorphologists, especially those working in densely populated regions, tend to see human impact throughout the landscape (e.g. Wohl, 2013). Periglacial and glacial geomorphologists, mostly working in sparsely populated regions, tend to see vast expanses of tundra, boreal forest or ice sheets as fundamentally natural with little direct human impact. Aeolian geomorphologists, commonly working in drylands, recognise that aeolian landscapes increasingly are impinged upon by human activities, but any resultant landforms rarely, if ever, display features that allow their unequivocal distinction from the natural. Increasingly, however, all these process domains are being impacted by anthropogenically-driven climate change, albeit as mediated by the respective geomorphological reaction times. It is theoretically possible that even tectonic forces could be affected by human activities as there appears to be a correlation between zones of rapid uplift and intense precipitation, and this accords with model predictions where the trigger is a climate-driven increase in the erosion rate (Whipple, 2008). So by altering synoptic weather patterns, humans could influence some components of tectonic evolution, although it is likely that such influences would be small relative to other geodynamic forces.

The implication from the perspective provided by geomorphological considerations is that the putative Anthropocene should have an informal stratigraphic status accommodating a highly diachronous lower boundary. Formal identification essentially would be arbitrary and impractical under existing stratigraphic procedures (Lewin and Macklin, 2013) and would also be very unlikely to garner universal or even majority support amongst geomorphologists or the wider geoscience community. Where different outcomes are required, such as utilitarian information for society, Earth history can be told using other stratigraphic schemes, in which geomorphology has a prominent role in providing explanations for the form, composition and distribution of surface materials. Societal implications may include the maintenance of ecological functionality, ecosystem service provision and sustainability.

Two practical implications follow. First, the less obvious effects of humans on geomorphic systems warrant increased research. This is the 'knowledge for mitigation' that needs to be in place to advise policy makers. Second, we need to improve the criteria for diagnosing human impacts on 
the connectivity, integrity and resilience of critical zone processes, and this can be seen as an opportunity (Wohl, 2013). This recognition not only includes the development of existing techniques such as the remote sensing of land cover and landforms and the biogeochemical analysis of sediments, but also a new way of conceptualising the role of humans both through processes and materials within ecosystems as well as at the global scale. The geomorphological impact of new materials from geotextiles to smart concrete is clearly a part of an Anthropocene that we can recognise at a variety of spatial and temporal scales. While this scale dependency of the Anthropocene complicates its formal recognition in geological terms, it is a key element in the application of geomorphology for environmental management in a future world that may host nine billion people by mid-century.

Acknowledgements. The authors wish to thank everyone who supported the British Society for Geomorphology's Anthropocene Fixed Term Working Group. We also thank M. Lobb for the TLS data, L. Ertle for drafting assistance, and the staff of the Geological Society of London for provision of meeting space for Working Group meetings. We appreciate the comments of two anonymous referees that helped us to sharpen some aspects of the paper. This paper was made possible by funding to the Working Group from the British Society for Geomorphology.

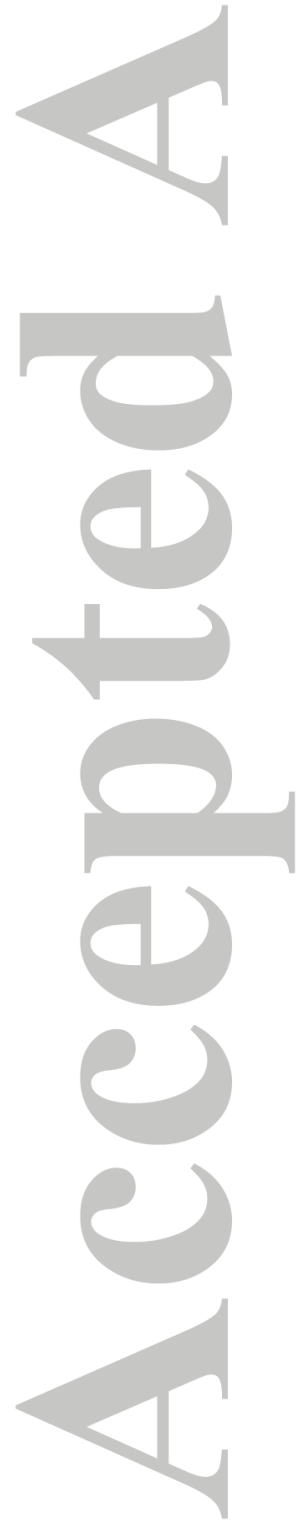

This article is protected by copyright. All rights reserved. 


\section{References}

Alfonso S, Grousset F, Massé L, Tastet J-P. 2001. A European lead isotope signal recorded from 6000 to 300 years BP in coastal marshes (SW France). Atmospheric Environment 35: 3595-3605.

Allen JRL. 1987. Toward a quantitative chemostratigraphic model for sediments of late Flandrian age in the Severn Estuary, U.K. Sedimentary Geology 53:73-100.

Allen JRL. 2003. An eclectic morphostratigraphic model for the sedimentary response to Holocene sea-level rise in northwest Europe. Sedimentary Geology 161: 31-54.

Allen JRL, Haslett S. 2014. Site formation processes in the Severn Estuary Levels. Annual Report of the Severn Estuary Levels Research Committee 22: 3-20.

Allen JRL, Rae JE. 1986. Time sequence of metal pollution, Severn Estuary, southwestern UK. Marine Pollution Bulletin 17: 427-431.

Ashkenazy Y, Yizhaq H, Tsoar H. 2012. Sand dune mobility under climate change in the Kalahari and Australian deserts. Climatic Change 112: 901-923.

Ballais J.-L. 1994. Aeolian activity, desertification and the Green Dam in the Ziban Range, Algeria. In Environmental Change in Drylands: Biogeographical and Geomorphological Perspectives, Millington AC, Pye K (eds). British Geomorphological Research Group Symposia Series, 177-198.

Ballantyne CK. 2002. Paraglacial geomorphology. Quaternary Science Reviews 21: 1935-2017.

Bateman MD, Godby SP. 2004. Late-Holocene inland dune activity in the UK: a case study from Breckland, East Anglia. The Holocene 14: 579-588.

Barchyn TE, Hugenholtz CH. 2013. Dune field reactivation from blowouts: Sevier Desert, UT, USA. Aeolian Research 11: 75-84.

Beets DJ, van der Spek AJF. 2000. The Holocene evolution of the barrier and the back-barrier basins of Belgium and the Netherlands as a function of late Weichselian morphology, relative sea-level rise and sediment supply. Geologie en Mijnbouw 79: 3-16.

Benazzouz MT, Boureboune L. 2009. Anthropic actions and desertification in Algeria. In Desertification and Risk Analysis Using High and Medium Resolution Satellite Data, Marini A, Talbi $M$ (eds). NATO Science for Peace and Security Series C - Environmental Security, Springer Science + Business Media BV; 3-18.

Berger A, Loutre MF. 2002. An exceptionally long interglacial ahead? Science 297: 1287-1288.

Blöthe $\mathrm{JH}$, Korup O. 2013. Millennial lag times in the Himalayan sediment routing system. Earth and Planetary Science Letters 382: 38-46.

Blott SJ, Pye K, van der Wal D, Neal A. 2006. Long-term morphological change and its causes in the Mersey Estuary, NW England. Geomorphology 81: 185-206.

Blum MD, Roberts HH. 2009. Drowning of the Mississippi Delta due to insufficient sediment supply and global sea-level rise. Nature Geoscience 2: 488-491.

Boyle J, Chiverrell R, Schillereff D. 2015a. Lacustrine archives of metals from mining and other industrial activities - a geochemical approach. In Environmental Contaminants: Using Natural Archives to Track Sources and Long-term Trends of Pollution, Blais JM, Rosen MR, Smol JP (eds). Developments in Paleoenvironmental Research, 18. Springer, Dordrecht; 121-159.

Boyle J, Chiverrell R, Davies H, Alderson DM. 2015b. An approach to modelling the impact of prehistoric farming on Holocene landscape phosphorus dynamics. The Holocene 25: 203-214.

Bracken LJ, Wainwright J. 2006. Geomorphological equilibrium: myth and metaphor? Transactions of the Institute of British Geographers 31: 167-178.

Brayshay BA, Dinnin M. 1999. Integrated palaeoecological evidence for biodiversity at the floodplainforest margin. Journal of Biogeography 26: 115-131.

Brown AG. 1988. The palaeoecology of Alnus (alder) and the Postglacial history of floodplain vegetation. Pollen percentage and influx data from the West Midlands, United Kingdom. New Phytologist 110: 425-436.

Brown AG. 1997. Alluvial Geoarchaeology: Floodplain Archaeology and Environmental Change. Cambridge Manuals in Archaeology, Cambridge University Press: Cambridge; 377 pp. 
Brown AG. 2008. Geoarchaeology, the four dimensional (4D) fluvial matrix and climatic causality. Geomorphology 101: 278-297.

Brown AG. 2016. Societal stability and environmental change: examining the archaeology-soil erosion paradox. Geoarchaeology in press.

Brown AG, Carey C, Erkens G, Fuchs M, Hoffmann T, Macaire JJ, Moldenhauer KM, Walling DE. 2009. From sedimentary records to sediment budgets: multiple approaches to catchment sediment flux. Geomorphology 108: 35-47.

Brown AG, Tooth S, Chiverrell R, Rose J, Thomas DSG, Wainwright J, Bullard J, Thorndycraft V, Aalto R, Downs P. 2013a. The Anthropocene: is there a geomorphological case? Earth Surface Processes and Landforms 38: 431-434.

Brown AG, Toms P, Carey C, Rhodes E. 2013b. Geomorphology of the Anthropocene: timetrangressive discontinuities of human-induced alluviation. Anthropocene 1: 3-13.

Brush G. 1989. Rates and patterns of estuarine sediment accumulation. Limnology and Oceanography 34: 1235-1246.

Bruun P. 1995. The development of downdrift erosion. Journal of Coastal Research 11: 1242-1257.

Caro T, Darwin J, Forrester T, Ledoux-Bloom C, Wells C. 2011. Conservation in the Anthropocene. Conservation Biology 26: 185-188

Carretero MI, Pozo M, Ruiz F, Rodríguez Vidal J, Cáceres LM, Abad M, Muñoz JM, Gómez F, Campos JM, González-Regalado ML, Olías M. 2011. Trace elements in Holocene sediments of the southern Doñana National Park (SW Spain): historical pollution and applications. Environmental Earth Sciences 64: 1215-1223.

Charlier RH, Chaineux MCP, Morcos S. 2005. Panorama of the history of coastal protection. Journal of Coastal Research 21: 79-111.

Chepstow-Lusty AJ, Frogley MR, Bauer BS, Leng MJ, Boessenkool KP, Carcaillet C, Ali AA, Gioda A. 2009. Putting the rise of the Inca Empire within a climatic and land management context. Climate of the Past 5: 375-388.

Chin A. 2006. Urban transformation of river landscapes in a global context. Geomorphology 79: 460487.

Chin A, O'Dowd AP, Gregory KJ. 2013. Urbanization and river channels. In Treatise on Geomorphology, Vol. 9, Fluvial Geomorphology, Shroder J (Editor in Chief), Wohl EE (ed.), Academic Press: San Diego, CA; 809-827.

Church M. 2010. The trajectory of geomorphology. Progress in Physical Geography 34: 265-286.

Clarke DW, Boyle JF, Lario J, Plater AJ. 2014. Meso-scale barrier estuary disturbance, response and recovery behaviour: evidence of system equilibrium and resilience from high-resolution particle size analysis. The Holocene 24: 357-369.

Cooper JAG, McKenna J, Jackson DWT, O'Connor M. 2007. Mesoscale coastal behaviour related to morphological self-adjustment. Geology 35: 187-190.

Corcoran PL, Moore CJ, Jazvac K. 2014. An anthropogenic marker horizon in the future rock record. GSA Today 24: 4-8.

Coulthard TJ, Van de Wiel MJ. 2012. Modelling river history and evolution. Philosophical Transactions of the Royal Society A 370: 2123-2142.

Crutzen PJ. 2002. Geology of mankind. Nature 415: 23.

Davies M, Hamza O, Harris C. 2001. The effect of rise in mean annual temperature on the stability of rock slopes containing ice-filled discontinuities. Permafrost and Periglacial Processes 12: 137144.

Davis RA, Welty AT, Borrego J, Morales JA, Pendón JG, Ryan JG. 2000. Rio Tinto estuary (Spain): 5000 years of pollution. Environmental Geology 39: 1107-1116.

Dearing JA, Jones RT. 2003. Coupling temporal and spatial dimensions of global sediment flux through lake and marine sediment records. Global and Planetary Change 39: 147-168.

Draut AE. 2012. Effects of river regulation on aeolian landscapes, Colorado River, southwestern USA. Journal of Geophysical Research - Earth Surface 117: F02022.

This article is protected by copyright. All rights reserved. 
Ellis EC. 2011. Anthropogenic transformation of the terrestrial biosphere. Philosophical Transactions of the Royal Society A 369: 1010-1035.

Erginal AE, Türkes M, Ertek TA, Baba A, Bayrakdar C. 2008. Geomorphological investigation of the excavation induced Dündar landslide, Bursa - Turkey. Geografiska Annaler: Series A, Physical Geography 90: 109-123.

Erskine WD, Saynor MJ. 2000. Assessment of the off-site geomorphic impacts of uranium mining on Magela Creek, Northern Territory, Australia. Environment Australia Supervising Scientist Report 156.

Evans DJA (ed.). 2003. Glacial Landsystems. Hodder Arnold.

Evans G. 2012. Deltas: the fertile dustbins of the continents. Proceedings of the Geologists' Association 123: 397-418.

Finney S. 2014. The 'Anthropocene' as a ratified unit in the ICS International Chronostratigraphic Chart: fundamental issues that must be addressed by the Task Group. In A Stratigraphical Basis for the Anthropocene, Waters CN, Zalasiewicz JA, Williams M, Ellis MA, Snelling AM (eds). Geological Society, London, Special Publications 395: 23-28.

Foley JA, DeFries R, Asner GP, Barford C, Bonan G, Carpenter SR. 2005. Global consequences of land use. Science 309: 570-574.

Foley JA, Gronenborn D, Andreae MO, Kadereit JW, Esper J, Scholz D, PöschI U, Jacob DE, Schöne BR, Schreg R, Vött A, Jordan D, Lelieveld J, Weller CG, Alt KW, Gaudzinski-Windheuser S, Bruhn K-C, Tost $H$, Sirocko F, Crutzen PJ. 2013. The Palaeoanthropocene - The beginnings of anthropogenic environmental change. Anthropocene 3: 83-88.

Fookes PG, Lee EM, Griffiths JS. 2009. Engineering Geomorphology: Theory and Practice. Whittles Publishing: Dunbeath.

Ford JR, Price SJ, Cooper AH, Waters CN. 2014. An assessment of lithostratigraphy for anthropogenic deposits. In A Stratigraphical Basis for the Anthropocene, Waters CN, Zalasiewicz JA, Williams M, Ellis MA, Snelling AM (eds). Geological Society, London, Special Publications 395: 55-90.

Fornos AM. 1995. The impact of human activities on the erosion and accretion of the Nile Delta coast. Journal of Coastal Research 11: 821-833

Frye JC, Willman HB. 1962. Note 27 - Morphostratigraphic units in Pleistocene stratigraphy. Bulletin of the American Association of Petroleum Geologists 46: 112-113.

Fryirs K. 2013. (Dis)connectivity in catchment sediment cascades: A fresh look at the sediment delivery problem. Earth Surface Processes and Landforms 38: 30-46.

Gale SJ, Hoare PG. 2012. The stratigraphic status of the Anthropocene. The Holocene 22: 1478-1481.

Garland GA. 1990. Technique for assessing erosion risk from mountain footpaths. Environmental Management 14, 793-798.

Gibbard PL, Head MJ, Walker MJC and the Subcommision on Quaternary Stratigraphy. 2009. Formal ratification of the Quaternary System/Period and the Pleistocene Series/Epoch with a base at 2.58 Ma. Journal of Quaternary Science 25, 96-102.

Gibbard PL, Walker MJC. 2014. The term 'Anthropocene' in the context of formal geological classification. In A Stratigraphical Basis for the Anthropocene, Waters CN, Zalasiewicz JA, Williams M, Ellis MA, Snelling AM (eds). Geological Society, London, Special Publications 395: 29-37.

Gilbert GK. 1877. Report on the Geology of the Henry Mountains. United States Geological and Geographical Survey, Rocky Mountains Region. General Printing Office: Washington DC.

Gilbert GK. 1917. Hydraulic-Mining Debris in the Sierra Nevada. United States Geological Survey Professional Paper 105.

Graf W. 2001. Damage control: restoring the physical integrity of America's rivers. Annals of the Association of American Geographers 91: 1-27.

Gurnell AM, Lee M, Souch C. 2007. Urban rivers: hydrology, geomorphology, ecology and opportunities for change. Geography Compass 1: 1118-1137.

This article is protected by copyright. All rights reserved. 
Haeberli W, Noetzli J, Arenson L, Delaloye R, Gärtner-Roer I, Gruber S, Isaksen K, Kneisel C, Krautblatter M, Phillips M. 2010. Mountain permafrost: development and challenges of a young research field. Journal of Glaciology 56: 1043-1058.

Haff PK. 2010. Hillslopes, rivers, plows, and trucks: mass transport on Earth's surface by natural and technological processes. Earth Surface Processes and Landforms 35: 1157-1166.

Hahnenberger M, Nicoll K. 2014. Geomorphic and land cover identification of dust sources in the eastern Great Basin of Utah, USA. Geomorphology 204:657-672.

Happ SC, Rittenhouse G, Dobson GC. 1940. Some Principles of Accelerated Stream and Valley Sedimentation. Technical Bulletin 695. United States Department of Agriculture, Washington DC; $133 \mathrm{pp}$.

Harrison AM, Plim JFM, Harrison M, Jones LD, Culshaw MG. 2012. The relationship between shrinkswell occurrence and climate in south-east England. Proceedings of the Geologists' Association 123: 556-575.

Haslett SK, Davies P, Curr RHF, Davies CFC, Kennington K, King CP, Margetts AJ. 1998. Evaluating lateHolocene relative sea-level change in the Somerset Levels, southwest Britain. The Holocene 8: 197-207.

Havelock G, 2009. Palaeosalinity Change in the Taw Estuary, South-West England: Response to Late Holocene River Discharge and Relative Sea-Level Change. Unpublished PhD Thesis, University of Exeter.

Heimsath AM, Dietrich WE, Nishiizumi K, Finkel RC. 1997. The soil production function and landscape equilibrium. Nature 388: 358-361.

Heimsath AM, Chappell J, Dietrich WE, Nishiizumi K, Finkel RC. 2000. Soil production on a retreating escarpment in southeastern Australia. Geology 28: 787-790.

Hedberg HD. (ed.). 1976. International Stratigraphic Guide: A Guide to Stratigraphic Classification, Terminology and Procedure, by the International Subcommission on Stratigraphic Classification of IUGS Commission of Stratigraphy. Wiley Interscience Publication, New York.

Herman F, Seward D, Valla PG, Carter A, Kohn B, Willett SD, Ehlers TA. 2013. Worldwide acceleration of mountain erosion under a cooling climate. Nature 504: 423-426

Hoffmann T, Thorndycraft VR, Brown AG, Coulthard TJ, Damnati B, Kale VS, Middelkoop H, Notebaert B, Walling DE. 2010. Human impact on fluvial regimes and sediment flux during the Holocene: review and future research agenda. Global and Planetary Change 72: 87-98.

Hooke JM. 2006. Human impacts on fluvial systems in the Mediterranean region. Geomorphology 79: 311-335.

Hooke R LeB. 1994. On the efficacy of humans as geomorphic agents. GSA Today 4: 224-225.

Hooke R LeB. 2000. On the history of humans as geomorphic agents. Geology 28: 843-846.

Hooke R LeB. 2012. Land transformation by humans: a review. GSA Today 22: 4-10.

Holmes PM, Thomas DSG, Bateman MD, Wiggs GFS, Rabumbulu M. 2012. Evidence for land degradation from aeolian sediment in the western central Free State Province, South Africa. Land Degradation and Development 23: 601-610.

Hudson PF, Middelkoop H, Stouthamer E. 2008. Flood management along the Lower Mississippi and Rhine Rivers (The Netherlands) and the continuum of geomorphic adjustment. Geomorphology 101: 209-236.

Hudson-Edwards KA, Macklin MG, Finlayson R, Passmore DG. 1999. 2000 years of sediment-borne heavy metal storage in the Yorkshire Ouse, northeast England. Hydrological Processes 13: 10871102.

Hulme M. 2009. Why We Disagree about Climate Change. Cambridge University Press, Cambridge.

Hupy JP, Koehler T. 2012. Modern warfare as a significant form of zoogeomorphic disturbance upon the landscape. Geomorphology 157-158: 169-182.

Hutchinson JN. 2001. Reading the ground: morphology and geology in site appraisal. Engineering Geology and Hydrogeology 34: 7-50. 
James LA. 2004. Tailings fans and valley-spur cutoffs created by hydraulic mining. Earth Surface Processes and Landforms 29: 869-882.

James LA. 2005. Sediment from hydraulic mining detained by Englebright and small dams in the Yuba basin. Geomorphology 71: 202-226.

James LA. 2013. Legacy sediment: definitions and processes of episodically produced anthropogenic sediment. Anthropocene 2:16-26.

Jennings S, Orford J, Canti M, Devouy R, Straker V. 1998. The role of relative sea-level rise and changing sediment supply on Holocene barrier development: the example of Porlock, Somerset. The Holocene 8: 165-181.

Jensen DW, Steel EA, Fullerton AH, Pess GR. 2009. Impact of fine sediment on egg-to-fry survival of Pacific Salmon: a meta-analysis of published studies. Reviews in Fisheries Science 17: 348-359.

Jordan H, Hamilton K, Lawley S, Price S. 2016. Anthropogenic contribution to the geological and geomorphological record: a case study from Great Yarmouth, Norfolk, UK. Geomorphology 253: 534-546.

Kinnell PIA. 2005. Why the universal soil loss equation and the revised version of it do not predict event erosion well. Hydrological Processes 19: 851-854.

Kirtman B, Power SB, Adedoyin JA, Boer GJ, Bojariu R, Camilloni I, Doblas-Reyes FJ, Fiore AM, Kimoto M, Meehl GA, Prather M, Sarr A, Schär C, Sutton R, van Oldenborgh GJ, Vecchi G, Wang HJ. 2013. Near-term Climate Change: Projections and Predictability. In Climate Change 2013: The Physical Science Basis. Contribution of Working Group I to the Fifth Assessment Report of the Intergovernmental Panel on Climate Change, Stocker TF, Qin D, Plattner GK, Tignor M, Allen SK, Boschung J, Nauels A, Xia Y, Bex V and Midgley PM (eds). Cambridge University Press: Cambridge, UK and New York, NY, USA.

Knight J, Harrison S. 2014. Limitations of uniformitarianism in the Anthropocene. Anthropocene 5: 71-75.

Knighton AD. 1989. River adjustment to changes in sediment load: the effects of tin mining on Ringarooma River, Tasmania. Earth Surface Processes and Landforms 14: 333-359.

Kokelj SV, Jorgenson MT. 2013. Advances in thermokarst research. Permafrost and Periglacial Processes 24: 108-119.

Kosmas CS, Moustakas N, Danalatos NG, Yassoglou N. 1996. The effect of land use change on soil properties and erosion along a catena. In Mediterranean Desertification and Land Use, Thornes J, Brandt J (eds). John Wiley and Sons: Chichester; 207-227.

Koven C, Riley W, Stern A. 2013. Analysis of permafrost thermal dynamics and response to climate change in the CMIP5 Earth System Models. Journal of Climate 26: 1877-1900.

Krautblatter M, Funk D, Günzel FK. 2013. Why permafrost rocks become unstable: a rock-icemechanical model in time and space. Earth Surface Processes and Landforms 38: 867-887.

Laimer HJ, Mulleger M. 2012. Geomorphological and geotechnical causes of anthropogenically induced rock-mass falls in the Wachau-Danube Valley (Bohemian Massif, Lower Austria). Geografiska Annaler: Series A, Physical Geography 94: 157-174.

Lawrence DM, Slater AG, Swenson SC. 2012. Simulation of present-day and future permafrost and seasonally frozen ground conditions in CCSM4. Journal of Climate 25: 2207-2225.

Leopold LB, Miller JP. 1954. A Post-Glacial Chronology for some Alluvial Valleys in Wyoming. Geological Survey Water Supply Paper 1261.

Lewin J. 2013. Enlightenment and the GM floodplain. Earth Surface Processes and Landforms 38: 1729.

Lewin J, Macklin MG. 2003. Preservation potential for Late Quaternary river alluvium. Journal of Quaternary Science 18: 107-120.

Lewin J, Macklin MG. 2013. Marking time in Geomorphology: should we try to formalise an Anthropocene definition? Earth Surface Processes and Landforms 39, 133-137.

Lewis SL, Maslin MA. 2015. Defining the Anthropocene. Nature 519: 171-180.

This article is protected by copyright. All rights reserved. 
Li G, Chen J, Ji J, Yang J, Conway TM. 2009. Natural and anthropogenic sources of East Asian dust. Geology 37: 727-730.

Li P, Qian H, Wu J. 2014. Environment: Accelerate research on land creation. Nature 510: 29-31.

Lisle TE. 1989. Sediment transport and resulting deposition in spawning gravels, North Coastal California. Water Resources Research 25: 1303-1319.

Lobb M, Brown AG. in press. Terrestrial Laser Scanning and coastal erosion at Low Hauxley. In Excavations at Low Hauxley, Northumberland, Waddington C (ed.). Archaeological Research Services Monograph: Sheffield, UK.

Lukas S. 2006. Morphostratigraphic principles in glacier reconstruction - a perspective from the British Younger Dryas. Progress in Physical Geography 30: 719-736.

Macklin MG, Jones A, Lewin J. 2010. River response to rapid Holocene environmental change: evidence and explanation in British catchments. Quaternary Science Reviews 29: 13-14.

Marker ME. 1967. The Dee estuary: its progressive silting and salt marsh development. Transactions of the Institute of British Geographers 41: 65-71.

Marsh GP. 1874. The Earth as Modified by Human Action. C. Scribner: New York.

Martín-Duque JF, Sanz MA, Bodoque JM, Lucía A, Martín-Moreno C. 2010. Restoring earth surface processes through landform design: a 13-year monitoring of a geomorphic reclamation model for quarries on slopes. Earth Surface Processes and Landforms 35: 531-548.

Marx SK, McGowan HA, Kamber BS, Knight, JM, Denholm J, Zawadzki A. 2014. Unprecedented wind erosion and perturbation of surface geochemistry marks the Anthropocene in Australia. Journal of Geophysical Research - Earth Surface 119: 45-61.

Masson-Delmotte V, Schulz M, Abe-Ouchi A, Beer J, Ganopolski A, González Rouco JF, Jansen E, Lambeck K, Luterbacher J, Naish T, Osborn T, Otto-Bliesner B, Quinn T, Ramesh R, Rojas M, Shao $X$, Timmermann A. 2013. Information from Paleoclimate Archives. In Climate Change 2013: The Physical Science Basis. Contribution of Working Group I to the Fifth Assessment Report of the Intergovernmental Panel on Climate Change, Stocker TF, Qin D, Plattner G-K, Tignor M, Allen SK, Boschung J, Nauels A, Xia Y, Bex V, Midgley PM (eds). Cambridge University Press: Cambridge, UK and New York, NY, USA; 383-464.

Mauz B, Hilger W, Muller MJ, Zoller L, Dikau R. 2005. Aeolian activity in Schleswig-Holstein (Germany): landscape response to Late Glacial climate change and Holocene human impact. Zeitschrift für Geomorphologie 49: 417-431.

McCarthy TS, Tooth S, Kotze DC, Collins N, Wandrag G, Pike T. 2010. The role of geomorphology in evaluating remediation options for floodplain wetlands: the case of Ramsar-listed Seekoeivlei, eastern South Africa. Wetlands Ecology and Management 18: 119-134.

McConnell, JR, Aristarain AJ, Banta JR, Edwards PR, Simões JC. 2007. 20th-Century doubling in dust archived in an Antarctic Peninsula ice core parallels climate change and desertification in South America. Proceedings of the Natural Academy of Sciences 104: 5743-5748.

McMillan AA, Merritt JW. 2012. A new Quaternary and Neogene lithostratigraphical framework for Great Britain and the Isle of Man. Proceedings of the Geologists' Association 123: 679-691.

Mead WR. 1954. Ridge and furrow in Buckinghamshire. Geographical Journal 120: 34-42.

Millennium Ecosystem Assessment. 2005. Ecosystems and Human Well-being: Synthesis. Island Press: Washington, DC.

Monastersky R. 2015. The human age. Nature 519: 144-147.

Montgomery DR. 2007. Soil erosion and agricultural sustainability. Proceedings of the National Academy of Sciences 104: 13268-13272.

Mossa J, James LA. 2013. Impacts of mining on geomorphic systems. In Treatise on Geomorphology, Vol. 13, Geomorphology of Human Disturbances, Climate Change, and Natural Hazards, Shroder J (Editor in Chief), James LA, Harden CP, Clague JJ (eds), Academic Press: San Diego, CA; 74-95.

Mudie $P$, Byrne R. 1980. Pollen evidence for historical sedimentation rates in California coastal marshes. Estuarine and Coastal Marine Science 10: 305-316. 
Mulitza S, Heslop, D, Pittauerova, D, Fischer HW, Meyer I, Stuut J-B, Zabel M, Mollenhauer G, Collins JA, Kuhnert H, Schulz M. 2010. Increase in African dust flux at the onset of commercial agriculture in the Sahel region. Nature 466: 226-228.

Murton JB. 2009. Global warming and thermokarst. In Permafrost Soils, Soil Biology Vol. 16. Margesin R (ed.). Springer-Verlag: Berlin Heidelberg; 185-203.

Neff JC, Ballantyne AP, Farmer GL, Mahowald NM, Conroy JL, Landry CC, Overpeck JT, Painter TH, Lawrence CR, Reynolds RL. 2008. Increasing eolian dust deposition in the western United States linked to human activity. Nature Geosciences 1: 189-195.

Nicolau JM, Asensio E. 2000. Rainfall erosion of opencast coal-mine lands: ecological perspective. In Reclaimed Land: Erosion Control, Soils and Ecology, Haigh MJ (ed.). Balkema: Rotterdam; 51-73.

Notebaert B, Verstraeten G, Ward P, Renssen H, Van Rompaey A. 2011. Modelling the sensitivity of sediment and water runoff dynamics to Holocene climate and land use changes at the catchment scale. Geomorphology 126: 18-31.

Nyssen J, Vermeersch D. 2010. Slope aspect affects geomorphic dynamics of coal mining spoil heaps in Belgium. Geomorphology 123: 109-121.

Osterkamp WR, Joseph WL. 2000. Climatic and hydrologic factors associated with reclamation. In Reclamation of Drastically Disturbed Lands, Barnishe IR, Darmody R, Daniels W (eds). American Society of Agronomy, Madison; 193-216.

Pirrie D, Hughes SH, Camm GS. 1999. Late Holocene sedimentation due to mine waste discharge, Fal Estuary. In The Quaternary of West Cornwall, Scourse JD, Furze MFA (eds). Field Guide. Quaternary Research Association: London; 113-121.

Parrish JD, Braun DP, Unnasch RS. 2003. Are we conserving what we say we are? Measuring ecological integrity within protected areas. Biosciences 53: 851-860.

Parsons, AJ, Wainwright J, Powell DM, Kaduk J, Brazier RE. 2004. A conceptual model for determining soil erosion by water. Earth Surface Processes and Landforms 29: 1293-1302.

Parsons AJ, Wainwright J, Brazier RE, Powell DM. 2006a. Is sediment delivery a fallacy? Earth Surface Processes and Landforms 31: 1325-1328.

Parsons AJ, Brazier RE, Wainwright J, Powell DM. 2006b. Scale relationships in hillslope runoff and erosion. Earth Surface Processes and Landforms 31: 1384-1393.

Paul JD. 2015. A question of uniformitarianism: has the geological past become the key to humanity's future? Anthropocene 9: 70-74.

Pickup G, Wasson RJ, Warner RF, Tongway D, Clark RL 1987. A Feasibility Study of Geomorphic Research for the Long Term Management of Uranium Mill Tailings. Divisional Report 87/2. CSIRO Division of Water Resources Research: Canberra.

Pinet P, Souriau M. 1998. Continental erosion and large-scale relief. Tectonics 7: 563-582.

Plater AJ, Appleby PG. 2004. Tidal sedimentation in the Tees estuary during the $20^{\text {th }}$ century: radionuclide and magnetic evidence of pollution and sedimentary response. Estuarine, Coastal and Shelf Science 60: 179-192.

Plater A, Kirby J. 2006. The potential for perimarine wetlands as an ecohydrological and phytotechnological management tool in the Guadiana estuary, Portugal. Estuarine, Coastal and Shelf Science 70: 98-108.

Plater AJ, Ridgway J, Appleby PG, Berry A, Wright MR. 1998. Historical contaminant fluxes in the Tees estuary, UK; geochemical, magnetic and radionuclide evidence. Marine Pollution Bulletin 37: 343360.

Price SJ, Ford JR, Cooper AH, Neal C. 2011. Humans as major geological and geomorphological agents in the Anthropocene: the significance of artificial ground in Great Britain. Philosophical Transactions of the Royal Society A 369: 1056-1084.

Reyes AV, Froese DG, Jensen BJL. 2012. Permafrost response to last interglacial warming: field evidence from non-glaciated Yukon and Alaska. Quaternary Science Reviews 29: 3256-3274.

This article is protected by copyright. All rights reserved. 
Rhoads BL, Thorn CE. 1996. Toward a philosophy of geomorphology. In The Scientific Nature of Geomorphology: Proceedings of the 27th Binghamton Symposium in Geomorphology held 27-29 September 1996, Rhoads BL, Thorn CE (eds). John Wiley and Sons: Chichester; 115-143.

Risse LM, Nearing MA, Nicks AD, Laflen JM. 1993. Assessment of error in the Universal Soil Loss Equation. Journal of the Soil Science Society of America 57:825-833.

Ritchie JC, McHenry JR. 1990. Application of radioactive fallout cesium-137 for measuring soil erosion and sediment accumulation rates and patterns: a review. Journal of Environmental Quality 19: 215-233.

Ronov AB. 1983. The Earth's sedimentary shell: quantitative patterns of its structure, composition and evolution. American Geological Institute Reprint Series 5: 1-73.

Rose J. 2010. The Quaternary of the British Isles: factors forcing environmental change. Journal of Quaternary Science 25: 399-418.

Roskin J, Katra I, Blumberg DG. 2013. Late Holocene dune mobilizations in the northwestern Negev dunefield, Israel: a response to combined anthropogenic activity and short-term intensified windiness. Quaternary International 303: 10-23.

Ruddiman WF. 2003. The anthropogenic greenhouse era began thousands of years ago. Climatic Change 61: 261-293.

Saito Y, Yang Z, Hori K. 2001. The Huanghe (Yellow River) and Changjiang (Yangtze River) deltas: a review on their characteristics, evolution and sediment discharge during the Holocene. Geomorphology 41: 219-231

Salvador A (ed.). 1994. International Stratigraphic Guide: A Guide to Stratigraphic Classification, Terminology, and Procedure (No. 30). Geological Society of America; 214 pp.

Sandgren P, Fredskild, B. 1991. Magnetic measurements recording Late Holocene man-induced erosion in S. Greenland. Boreas 20: 315-331.

Schneider A, MA Fried MA, Potere D. 2009 A new map of global urban extent from MODIS satellite data. Environmental Research Letters 4: 1-11.

Sear DA. 1993. Fine sediment infiltration into gravel spawning beds within a regulated river experiencing floods: Ecological implications for salmonids. Regulated Rivers: Research and Management 8: 373-390.

Sekovski I, Newton A, Dennison WC. 2012. Megacities in the coastal zone: using a driver-pressurestate-impact-response framework to address complex environmental problems. Estuarine, Coastal and Shelf Science 96: 48-59.

Shia P, Yana P, Yuana Y, Nearing M. 2004. Wind erosion research in China: past, present and future. Progress in Physical Geography 28: 366-386.

Singer MB, Aalto RE, James LA, Kilham NE, Hison JL, Ghoshal S. 2013. Enduring legacy of a toxic fan via episodic redistribution of California gold mining debris. Proceedings of the National Academy of Sciences 110: 18436-18441.

Small C, Nicholls RJ. 2003. A global analysis of human settlement in coastal zones. Journal of Coastal Research 19: 584-599.

Small EE, Anderson RS, Hancock GS. 1999. Estimates of the rate of regolith production using ${ }^{10} \mathrm{Be}$ and ${ }^{26} \mathrm{Al}$ from an alpine hillslope. Geomorphology 27: 131-150.

Sofia G, Dalla Fontana G, Tarolli P. 2014a. High-resolution topography and anthropogenic feature extraction: testing geomorphometric parameters in floodplains. Hydrological Processes 28: 20462061.

Sofia G, Mariniello F, Tarolli P. 2014b. A new landscape metric for the identification of terraced sites: the Slope Local Length of Auto-Correlation (SLLAC). ISPRS Journal of Photogrammetry and Remote Sensing 96: 123-133.

Sofia G, Prosdocimi M, Dalla Fontana G, Tarolli P. 2014c. Evidences and effects of changes in the artificial drainage network during the past half-century: a case study in the Veneto floodplain (Italy). Anthropocene 6, 48-62.

This article is protected by copyright. All rights reserved. 
Stevens CJ, Fuller DQ. 2012. Did Neolithic farming fail? The case for a Bronze Age agricultural revolution in the British Isles. Antiquity 86: 707-722.

Syvitski JPM, Smith JN, Calabrese EA, Boudreau BP. 1988. Basin sedimentation and the growth of prograding deltas. Journal of Geophysical Research 93: 6895-6908.

Syvitski JPM, Vörösmart CJ, Kettner AJ, Green P. 2005. Impact of humans on the flux of terrestrial sediment to the global coastal ocean. Science 308: 376-380.

Syvitski J, Peckham SD, Hilberman R, Mulder T. 2003. Predicting the terrestrial flux of sediment to the global ocean: a planetary perspective. Sedimentary Geology 162: 5-24.

Szabó J, Dávid L, Loczy D (eds). 2010. Anthropogenic Geomorphology: A Guide to Man-Made Landforms, Springer Science+Business Media B.V.: Dordrecht-Heidelberg-London-New York.

Taberlet P, Coissac E, Pompanon F, Gielly L, Miquel C, Valentini A, Vermat T, Corthier G, Brochmann C, Willerslev E. 2007. Power and limitations of the chloroplast trnL (UAA) intron for plant DNA barcoding. Nucleic Acids Research 35: e14.

Tarolli P, Sofia G 2016. Human topographic signatures and derived geomorphic processes across landscapes. Geomorphology 255: 140-161,

Tarolli P, Calligaro S, Cazorzi F, Dalla Fontana G. 2013. Recognition of surface flow processes influenced by roads and trails in mountain areas using high-resolution topography. European Journal of Remote Sensing 46: 176-197.

Tarolli P, Preti F, Romano N. 2014. Terraced landscapes: From an old best practice to a potential hazard for soil degradation due to land abandonment. Anthropocene 6: 10-25.

Tarolli P, Sofia G, Calligaro S, Prosdocimi M, Preti F, Dalla Fontana G. 2015. Vineyards in terraced landscapes: new opportunities from Lidar data. Land Degradation and Development 26: 92-102.

Thomas DSG, Knight M, Wiggs GFS. 2005. Remobilization of southern African desert dune systems by twenty first century global warming. Nature 435: 1218-1221.

Thomas DSG, Leason HE. 2005. Dunefield activity response to climate variability in the southwest Kalahari. Geomorphology 64: 117-132.

Thornbush M. 2015. Geography, urban geomorphology and sustainability. Area 47: 350-353.

Thorndycraft VR. 2013. Paleohydrology. In The Encyclopedia of Quaternary Science, Elias SA (ed.). Elsevier: Amsterdam; 3: 253-258.

Tsoar H, Møller JT. 1986. The role of vegetation in the formation of linear sand dunes. In Aeolian Geomorphology, Nickling WG (ed.). Allen and Unwin: Boston; 75-95.

Tooth S, Rodnight H, McCarthy TS, Duller GAT, Grundling A. 2009. Late Quaternary dynamics of a South African floodplain wetland and the implications for assessing recent human impacts. Geomorphology 106: 278-291

Vaughan DG, Comiso JC, Allison I, Carrasco J, Kaser G, Kwok R, Mote P, Murray T, Paul F, Ren J, Rignot E, Solomina O, Steffen K, Zhang T. 2013. Observations: Cryosphere. In Climate Change 2013: The Physical Science Basis. Contribution of Working Group I to the Fifth Assessment Report of the Intergovernmental Panel on Climate Change. In Stocker TF, Qin D, Plattner G-K, Tignor M, Allen SK, Boschung J, Nauels A, Xia Y, Bex V, Midgley PM (eds). Cambridge University Press: Cambridge, UK and New York, NY, USA; 317-382.

Wainwright J, Thornes JB. 2004. Environmental Issues in the Mediterranean: Processes and Perspectives from the Past and Present. Routledge: London.

Wainwright J, Turnbull L, Ibrahim TG, Lexarta-Artza I, Thornton SF, Brazier RE. 2011. Linking environmental regimes, space and time: interpretations of structures and functional connectivity. Geomorphology 126: 387-404.

Walker MJC, Berkelhammer M, Björck S, Cwynar LC, Fisher DA, Long AJ, Lowe JJ, Newnham RM, Rasmussen SO, Weiss H. 2012. Formal subdivision of the Holocene Series/Epoch: a Discussion Paper by the Intimate Working Group of INTIMATE (Integration of ice-core, marine and terrestrial records) and the Subcommission on Quaternary Stratigraphy (International Commission on Stratigraphy). Journal of Quaternary Science 27: 649-659.

Walton G, Lee MK. 2001. Geology for our Diverse Economy. British Geological Survey: Keyworth. 
Walling DE, Webb BW. 1996. Erosion and sediment yield: a global overview. In Erosion and Sediment Yield: Global and Regional Perspectives. IAHS Publication No. 236, 3-19.

Walsh K. 2014. The Archaeology of Mediterranean Landscapes. Cambridge University Press: Cambridge.

Walter RC, Merritts DJ. 2008. Natural streams and the legacy of water-powered mills. Science 319: 299-304.

Wang T, Yan CZ, Song X, Li S. 2013. Landsat images reveal trends in the aeolian desertification in a source area for sand and dust storms in China's Alashan plateau (1975-2007). Land Degradation and Development 24: 422-429.

Waters CN, Zalasiewicz JA, Williams M, Ellis MA, Snelling AM (eds). 2014a. A Stratigraphical Basis for the Anthropocene. Geological Society, London, Special Publications 395.

Waters CN, Zalasiewicz JA, Williams M, Ellis MA, Snelling AM. 2014b. A Stratigraphical Basis for the Anthropocene. In A Stratigraphical Basis for the Anthropocene, Waters CN, Zalasiewicz JA, Williams M, Ellis MA, Snelling AM (eds). Geological Society, London, Special Publications 395: 121.

Waters CN, Zalasiewicz JA, Summerhayes C, Barnosky AD, Poirier C, Gałuszka A., Cearreta A, Edgeworth $M$, Ellis EC, Ellis $M$, Jeandel C, Leinfelder R, McNeill JR, Richter D deB, Steffen W, Syvitski J, Vidas D, Wagreich M, Williams M, Zhisheng A, Grinevald J, Odada E, Oreskes N, Wolfe AP. 2016. The Anthropocene is functionally and stratigraphically distinct from the Holocene. Science 351: aad2622.

WGMS. 2008. Global glacier changes: facts and figures. In Zemp M, Roer I, Kääb A, Hoelzle M, Paul F, Haeberli WG (eds). UNEP and World Glacier Monitoring Service: Zurich, Switzerland; 88 pp.

Whipple KX. 2008. The influence of climate on the tectonic evolution of mountain belts. Nature Geoscience 2: 97-104.

Wiggs G, Holmes P. 2011. Dynamic controls on wind erosion and dust generation on west-central Free state agricultural land, South Africa. Earth Surface Processes and Landforms 36: 827-838.

Wilkinson B. 2005. Humans as geological agents: a deep time perspective. Geology 33: 161-164.

Wilkinson T. 2005. Soil erosion and valley fills in the Yemen Highlands and southern Turkey: integrating settlement, geoarchaeology, and climate change. Geoarchaeology 20: 169-192.

Wilkinson MT, Chappell J, Humphreys GS, Fifield K, Smith B, Hesse P. 2005. Soil production in heath and forest, Blue Mountains, Australia: influence of lithology and palaeoclimate. Earth Surface Processes and Landforms 30: 923-934.

Wittmann H, von Blanckenburg F, Maurice L, Guyot J-L, Kubik PW. 2011. Recycling of Amazon floodplain sediment quantified by cosmogenic ${ }^{26} \mathrm{Al}$ and ${ }^{10} \mathrm{Be}$. Geology 39: 467-470.

Wohl E. 2013. Wilderness is dead: Whither critical zone studies and geomorphology in the Anthropocene? Anthropocene 2: 4-15.

Wolanski E. 2006. The evolution time scale of macro-tidal estuaries: Examples from the Pacific Rim. Estuarine, Coastal and Shelf Science 66: 544-549.

Xing F, Kettner AJ, Ashton A, Giosan L, Ibáñez C, Kaplan JO. 2014. Fluvial response to climate variations and anthropogenic perturbations for the Ebro River, Spain in the last 4000 years. Science of the Total Environment 473-474: 20-31.

Zalasiewicz JA, Williams M, Fortey R, Smith A, Barry TL, Coe AL, Bown PR, Rawson PF, Gale A, Gibbard P, Gregory FJ, Hounslow MW, Kerr AC, Pearson P, Knox R, Powell J, Waters C, Marshall J, Oates M, Stone P. 2011. Stratigraphy of the Anthropocene. Philosophical Transactions of the Royal Society A 369: 1036-1055.

Zalasiewicz JA, Williams M, Waters CN. 2014. Can an Anthropocene Series be defined and recognised? In A Stratigraphical Basis for the Anthropocene, Waters CN, Zalasiewicz JA, Williams M, Ellis MA, Snelling AM (eds). Geological Society, London, Special Publications 395: 3-53. 
Table 1. Approaches to the measurement of natural erosion and denudation rates.

\begin{tabular}{|c|c|c|c|c|}
\hline Method & $\begin{array}{l}\text { Spatial Scale } \\
\left(\mathrm{m}^{2}\right)\end{array}$ & $\begin{array}{l}\text { Temporal } \\
\text { Scale } \\
\text { (years) }\end{array}$ & Limitations & $\begin{array}{l}\text { Example } \\
\text { references }\end{array}$ \\
\hline $\begin{array}{l}\text { Erosion plots } \\
\text { under natural } \\
\text { vegetation (incl. } \\
\text { Cs method) }\end{array}$ & $10^{2}-10^{3}$ & $10^{1}-10^{2}$ & $\begin{array}{l}\text { a) Assumption of naturalness of } \\
\text { vegetation including past soil history } \\
\text { b) Limited sample size } \\
\text { c) Restricted soil/bedrock types } \\
\text { d) Lack of representation of conditions } \\
\text { over multi-annual timescales because of } \\
\text { closure of the upper boundary of the plot } \\
\text { e) Poor recognition of controls on the } \\
\text { scales of operation of different parts of } \\
\text { the erosion process }\end{array}$ & $\begin{array}{l}\text { Ritchie and } \\
\text { McHenry, 1990; } \\
\text { Risse et al., 1993; } \\
\text { Kinnell, 2005; } \\
\text { Parsons et al., 2004, } \\
\text { 2006b }\end{array}$ \\
\hline $\begin{array}{l}\text { Natural river } \\
\text { basin sediment } \\
\text { loads }\end{array}$ & $10^{4}-10^{10}$ & $10^{1}-10^{2}$ & $\begin{array}{l}\text { a) Assumption of naturalness of } \\
\text { vegetation including past soil history } \\
\text { c) Storage assumptions (steady state) }\end{array}$ & $\begin{array}{l}\text { Walling and Webb, } \\
\text { 1996; Syvitski et al., } \\
2005\end{array}$ \\
\hline $\begin{array}{l}\text { Cosmogenic } \\
\text { isotope-based } \\
\text { basin } \\
\text { denudation } \\
\text { studies }\end{array}$ & $10^{4}-10^{10}$ & $10^{3}-10^{6}$ & $\begin{array}{l}\text { a) Storage constancy-assumption of } \\
\text { equilibrium } \\
\text { b) Non-anthropogenic climate change } \\
\text { c) Bias to hard lithologies (granites etc.) }\end{array}$ & $\begin{array}{l}\text { Small et al., 1999; } \\
\text { Heimsath et al., } \\
\text { 1997, 2000; } \\
\text { Wilkinson et al., } \\
2005\end{array}$ \\
\hline $\begin{array}{l}\text { Denudation } \\
\text { rates from } \\
\text { compositions of } \\
\text { sedimentary } \\
\text { rocks }\end{array}$ & Continental/global & $>10^{6} ?$ & $\begin{array}{l}\text { a) Very approximate mass estimates } \\
\text { b) Variable and unknown temporal scales }\end{array}$ & $\begin{array}{l}\text { Ronov, 1983: Pinet } \\
\text { and Souriau, } 1998\end{array}$ \\
\hline
\end{tabular}


Table 2. Factors that initiate, retard or counteract thermokarst activity (Murton, 2009). Human activities can affect many of these factors, either directly or indirectly.

\begin{tabular}{|c|c|c|c|}
\hline Scale & Factors & Initiating disturbances & Retarding or counteracting factors \\
\hline \multirow[t]{14}{*}{ Local } & Vegetation and & Damage or removal & Regrowth of vegetation \\
\hline & surface organic mat & Compaction of peat or organic soil & Accumulation of peat or organic soil \\
\hline & Water & Ponding on ground surface or underground & Drainage of ponds, lakes or cavities \\
\hline & & Flowing surface or groundwater & Refreezing of underground pools \\
\hline & & & Reduction or diversion of drainage \\
\hline & & Wetting of dry peat in summer & Drying of peat in summer \\
\hline & Snow cover & Thicker snow cover & Thinner snow cover \\
\hline & & Reduced snow density & Increased snow density \\
\hline & & Early snowmelt in summer & Late snowmelt in summer \\
\hline & Overburden & Soil erosion exposes ice-rich ground & Deposition of sediment \\
\hline & thickness & Artificial removal of soil & Burial of ice-rich ground by spoil \\
\hline & Artificial substrate & Laying of gravel pad too thin to contain seasonal & Thicker gravel pad \\
\hline & & freezing and thawing depth & Insulation placed beneath gravel \\
\hline & Artificial heat source & e.g. Heated buildings, pipelines, utilidors & $\begin{array}{l}\text { Dissipate heat (e.g. allow cold air } \\
\text { circulation or use thermosyphons) }\end{array}$ \\
\hline \multirow[t]{6}{*}{ Regional } & $\begin{array}{l}\text { Mean annual air } \\
\text { temperature }\end{array}$ & Climate warming & Climate cooling \\
\hline & Regional snowfall & Thickening snow cover & Thinning snow cover \\
\hline & & Early accumulation of snow in winter & Later accumulation of snow in winter \\
\hline & Summer weather & Unusually warm weather & Typical weather \\
\hline & Continentality & Increased continentality & Decreased continentality \\
\hline & Large forest fires & Damage vegetation or surface organic mat & Regrowth of forest \\
\hline
\end{tabular}




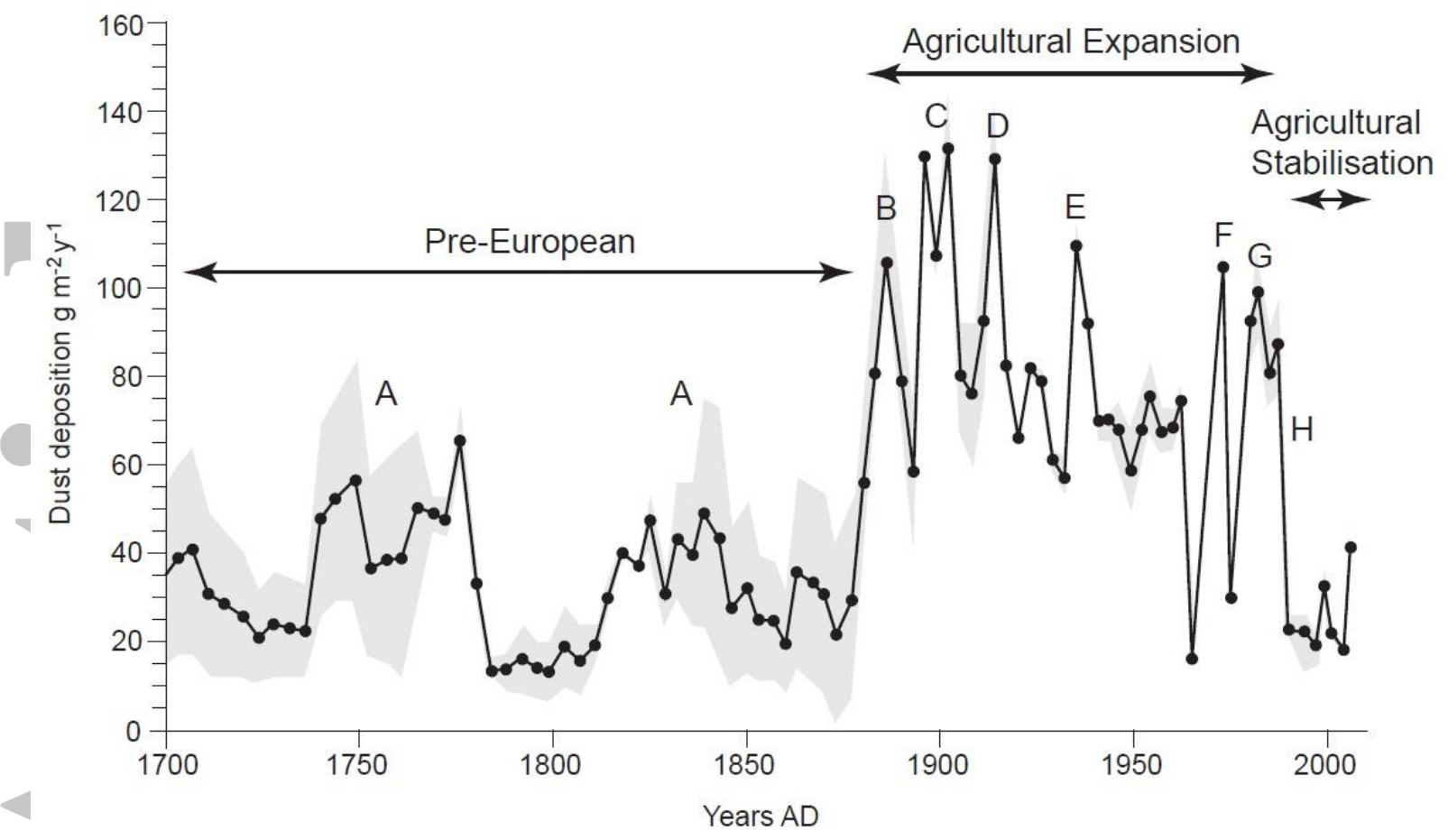

Figure 1. Dust deposition rates (AD 1700 to 2006) in the Snowy mire core (Marx et al., 2014). The grey outline shows 2 sigma errors. The letters on the plot refer to key events: $A=$ dust pulses during the Little Ice Age; $\mathrm{B}=$ the onset of agriculturally-induced wind erosion; $\mathrm{C}=$ the Federation Drought; $\mathrm{D}$ = the 1914 drought; $\mathrm{E}=$ the Dust Bowl era; $\mathrm{F}=$ the early 1970s and $\mathrm{G}=1980$ s droughts; and $\mathrm{H}=$ implementation of concerted soil conservation measures. 


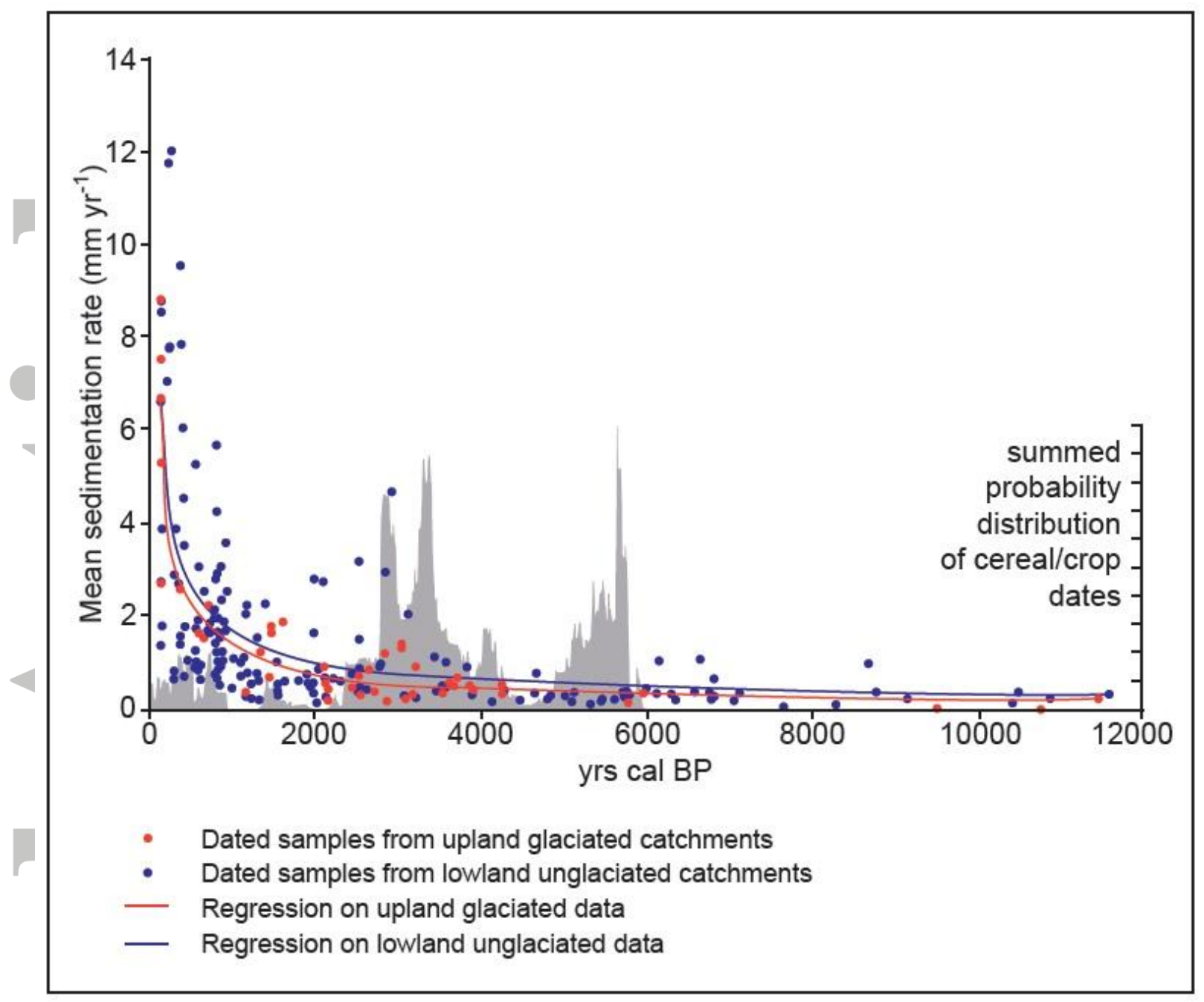

Figure 2. Radiocarbon-constrained Holocene floodplain sedimentation rates for the UK, with summed probability distribution of cereal/crop dates (derived from Macklin et al., 2010 and Stevens and Fuller, 2012). 


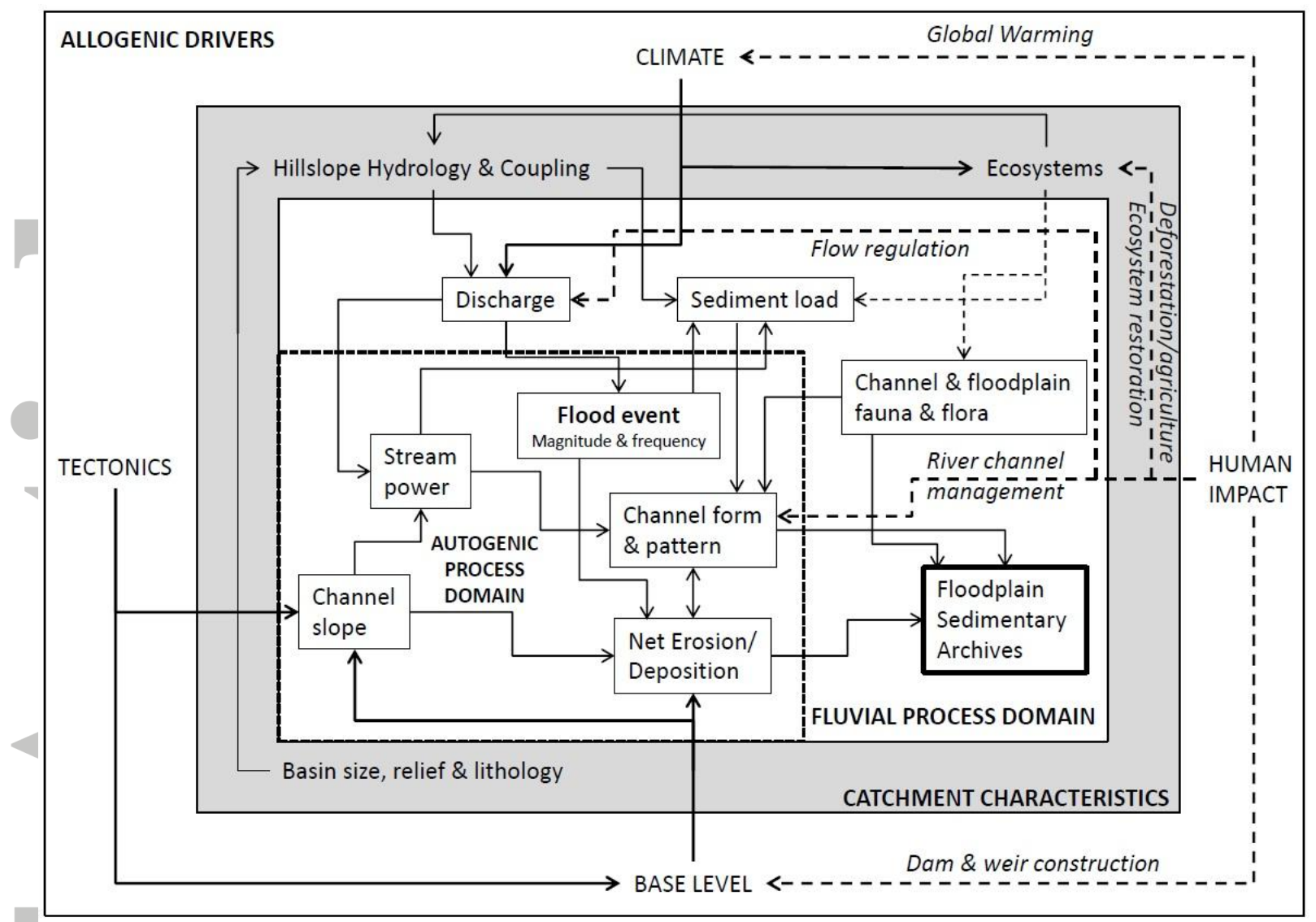

Fluvial System: centennial/millennial timescales

Figure 3. Summary of the fluvial system over 10-1000 year timescales. The diagram is divided into four areas: i) allogenic drivers; ii) catchment characteristics; and iii) the fluvial process domain, which includes iv) the autogenic process domain (image produced by V. Thorndycraft). The outer box includes the main allogenic drivers (at centennial-millennial timescales), including human impact. The grey box includes some general catchment characteristics that could produce spatially variable fluvial responses; within this box is the fluvial processes domain, with an inner box (dashed outline) showing key parts of the system affected by autogenic processes. Arrows show some key pathways operating within the fluvial system: black arrows show the natural allogenic drivers, grey arrows show the main processes, and dashed lines show the key human impacts. In italics are the key human impacts: note how they can influence all four areas of the diagram. The regional geography and geological setting of a particular river will influence the relative magnitude of the impacts of the natural and human drivers, and the signal of those drivers in alluvial sedimentary records will depend on catchment characteristics and autogenic processes that can influence geomorphic thresholds. 


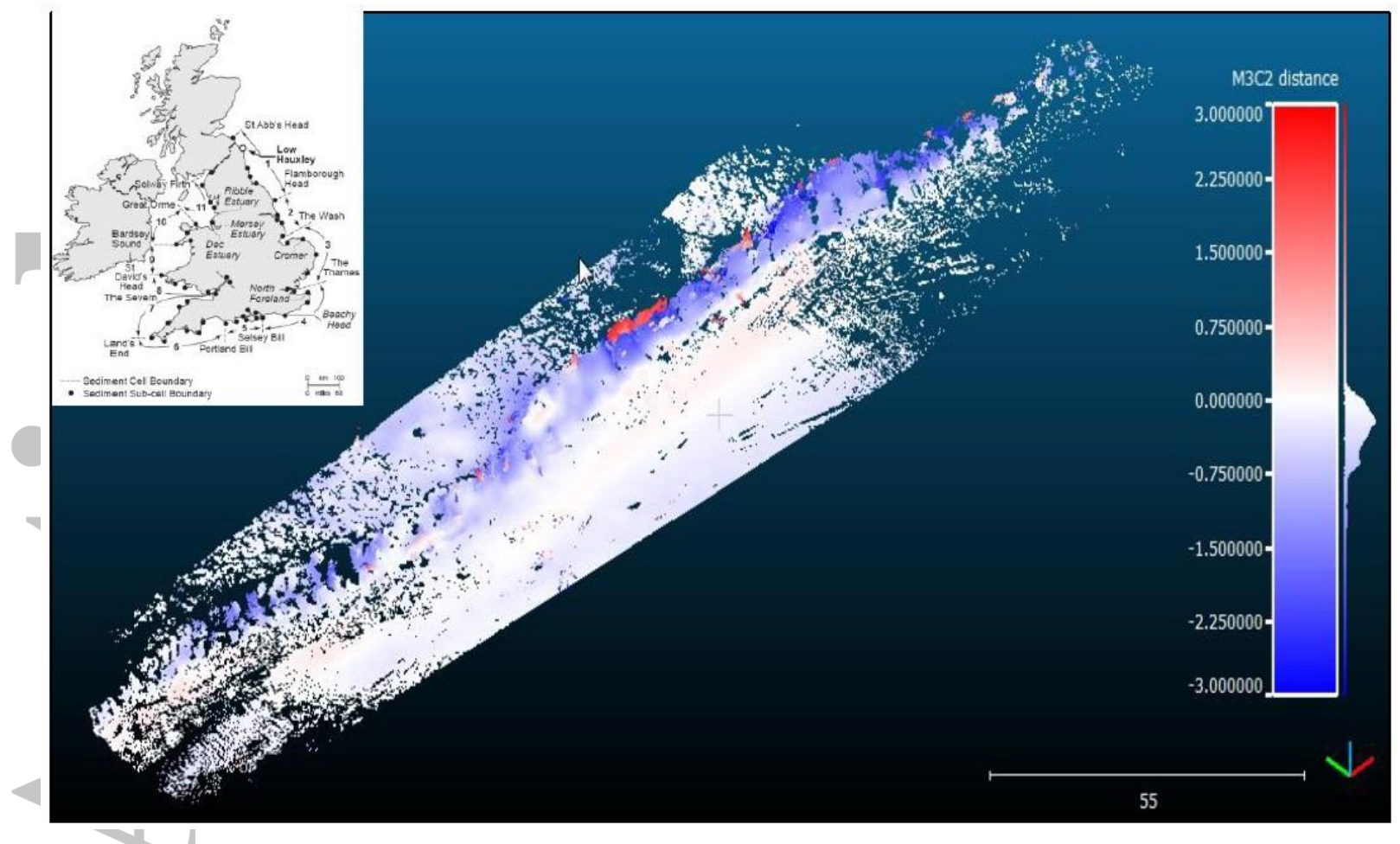

Figure 4. Oblique model of the results of a Terrestrial Laser Scanning survey of rapidly eroding Quaternary cliffs at Low Hauxley, Druridge Bay, northeast England. The image shows the difference (in metres) between scans in May 2013 and March 2014 and the cliff section is c. 100m long. The image was produced by M. Lobb using a Leica C10 Scanstation with CloudCompare $@$.

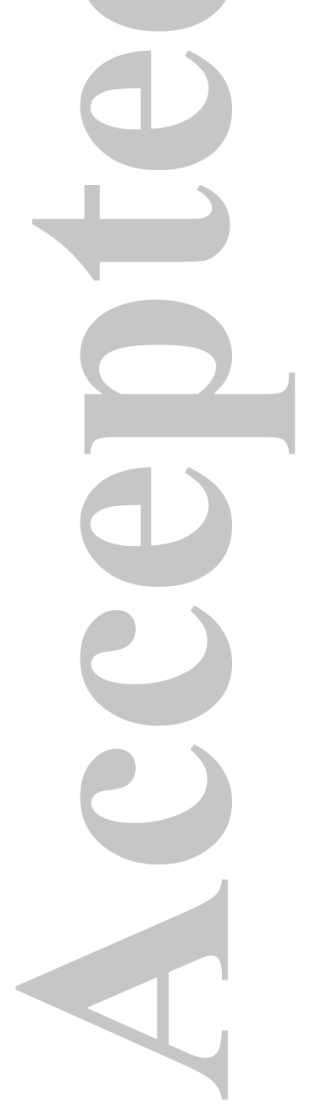

This article is protected by copyright. All rights reserved. 


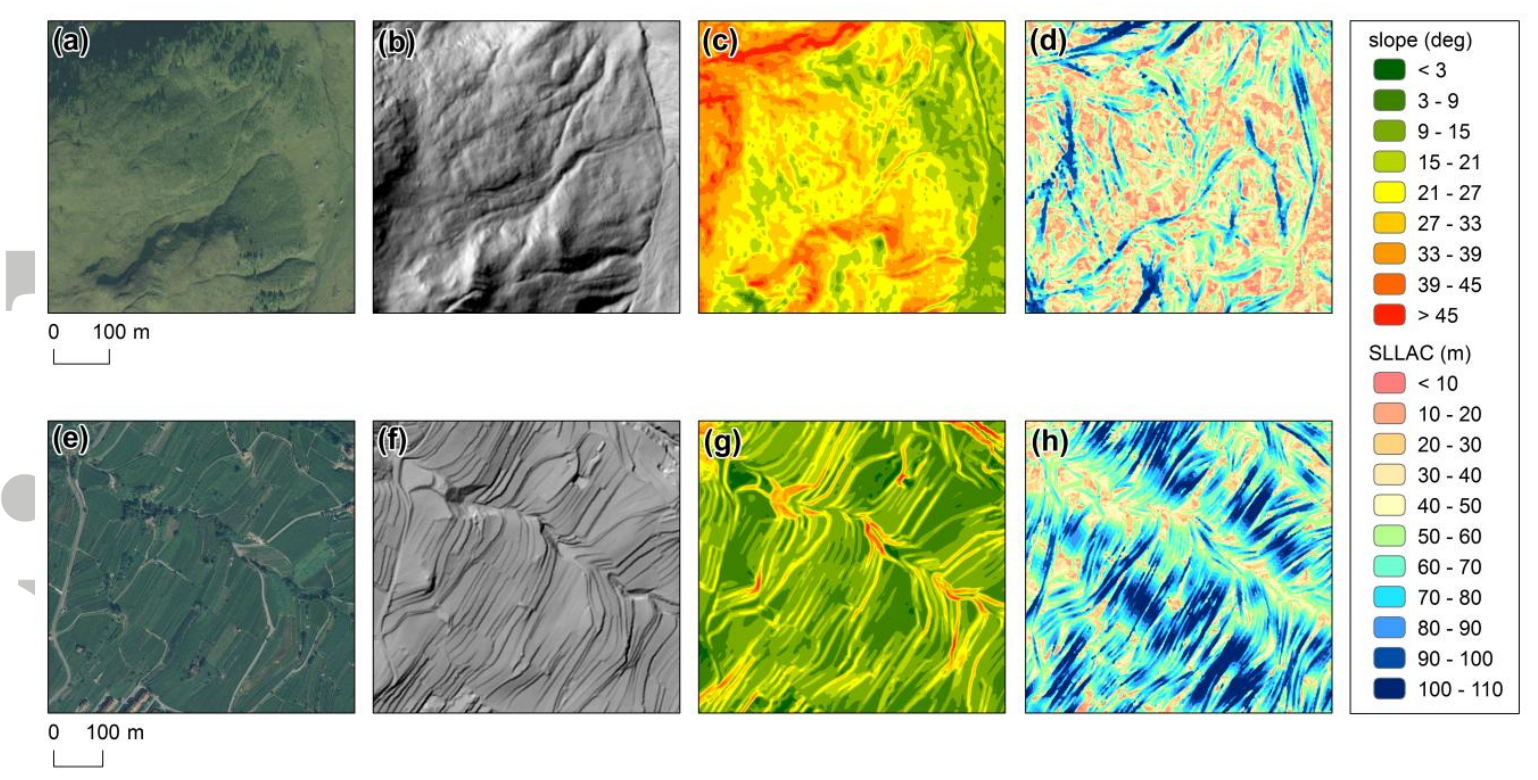

Figure 5. Images illustrating the detection of the anthropogenic topographic signature of terraced landforms in the Alpine context (Trento Province, central Italian Alps, Italy). Images of natural (a-d) and terraced landscapes (e-h) are derived from: aerial photographs (a and e); shaded relief maps derived by $2 \mathrm{~m}$ Lidar DTMs ( $\mathrm{b}$ and f); slope maps ( $\mathrm{c}$ and $\mathrm{g}$ ); and maps of Slope Local Length of AutoCorrelation (SLLAC) ( $d$ and h). The Lidar dataset is offered for free download by the Autonomous Province of Trento (Alps). Natural landscapes show maps of SLLAC with randomly distributed elements and a highly noisy background, whereas the construction of terraces leaves a clear topographic signature that results in more regular SLLAC maps with ordered elongated elements that follow the terrace benches.

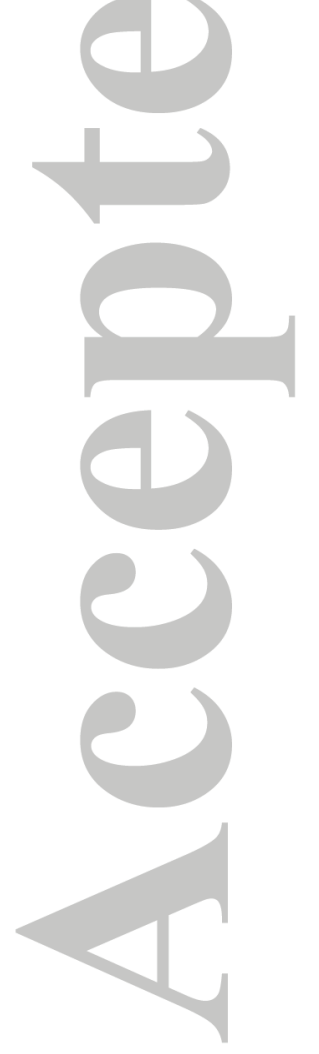



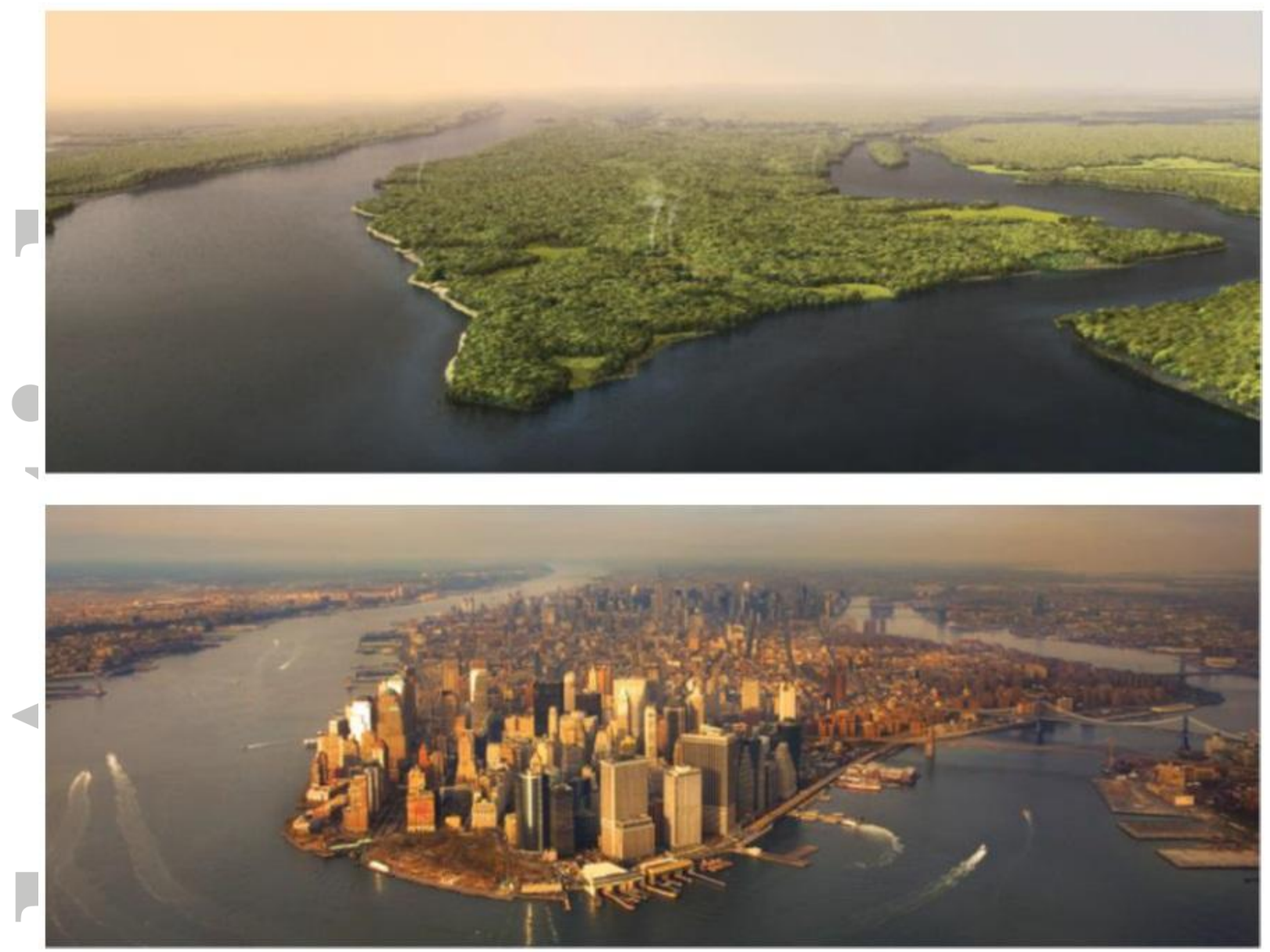

Figure 6. Images illustrating land transformation on Manhattan Island, east coast, USA. Top: artistic impression of the landscape before urban development (reproduced from National Geographic Magazine, September 2009, with permission of the National Geographic Society). Bottom: the present-day city of New York City (C Robert Clark/INSTITUTE for Artist Management). 

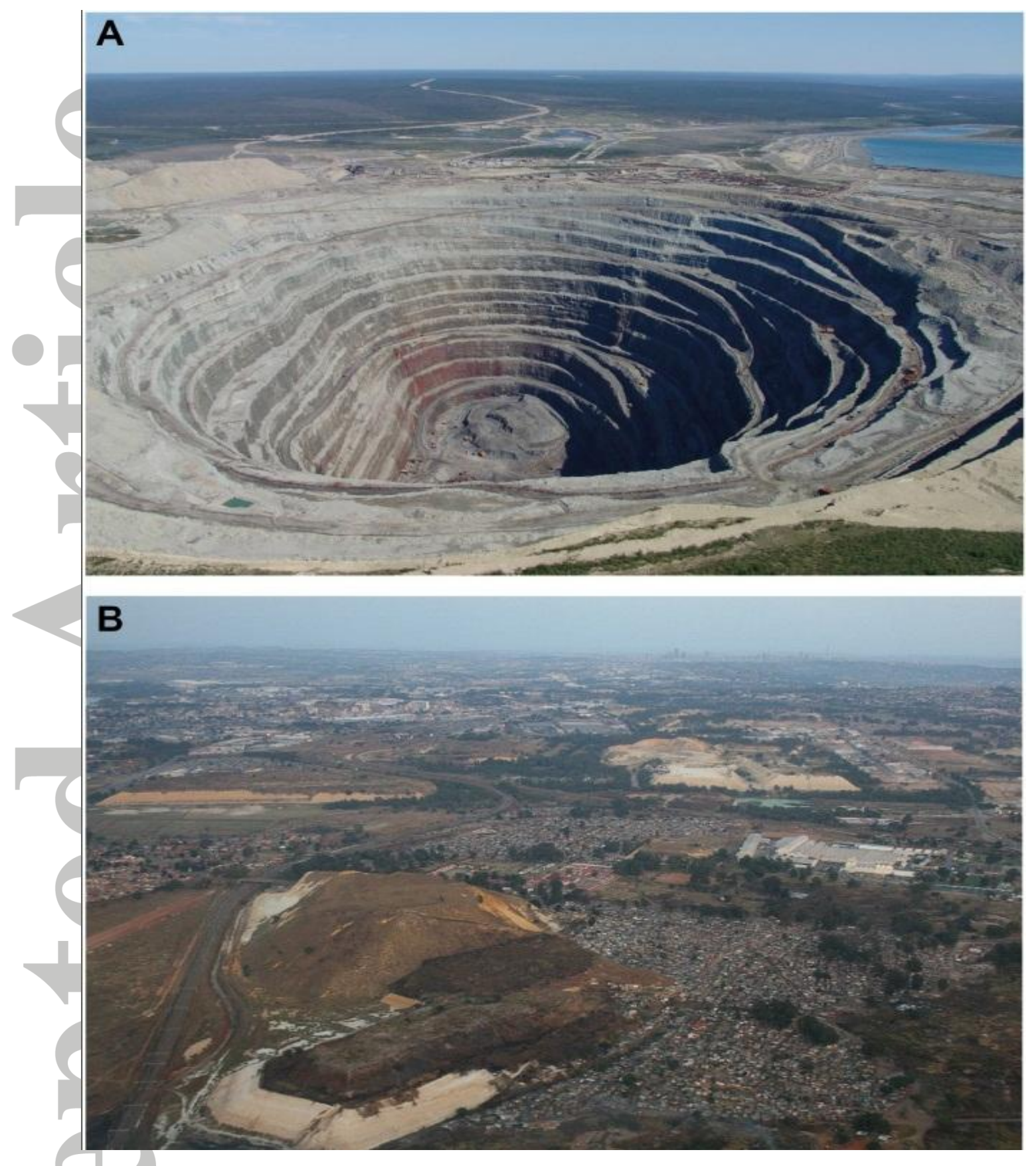

Figure 7. Oblique aerial views of mining-related landforms: A) the Udachnaya pipe, an opencast diamond mine in the Daldyn-Alakit kimberlite field in Sakha Republic, Russia. At more than $600 \mathrm{~m}$ deep, it is the third deepest opencast mine in the world. For scale, note the large vehicles around the sides and at the bottom of the mine. Photo licensed under the Creative Commons Attribution-Share Alike 3.0 Unported license; B) gold mining dumps (pale, partially vegetated areas) south of Johannesburg, South Africa. For scale, note the roads and the low rise dwellings adjacent to the dumps. Many other hundreds of dumps up to $\sim 50 \mathrm{~m}$ high dot the area around the central city (the skyline is just visible on the horizon), and stand testament to the major transformation of the landscape that has taken place since the late 19th Century.

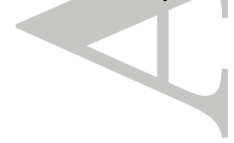

This article is protected by copyright. All rights reserved. 


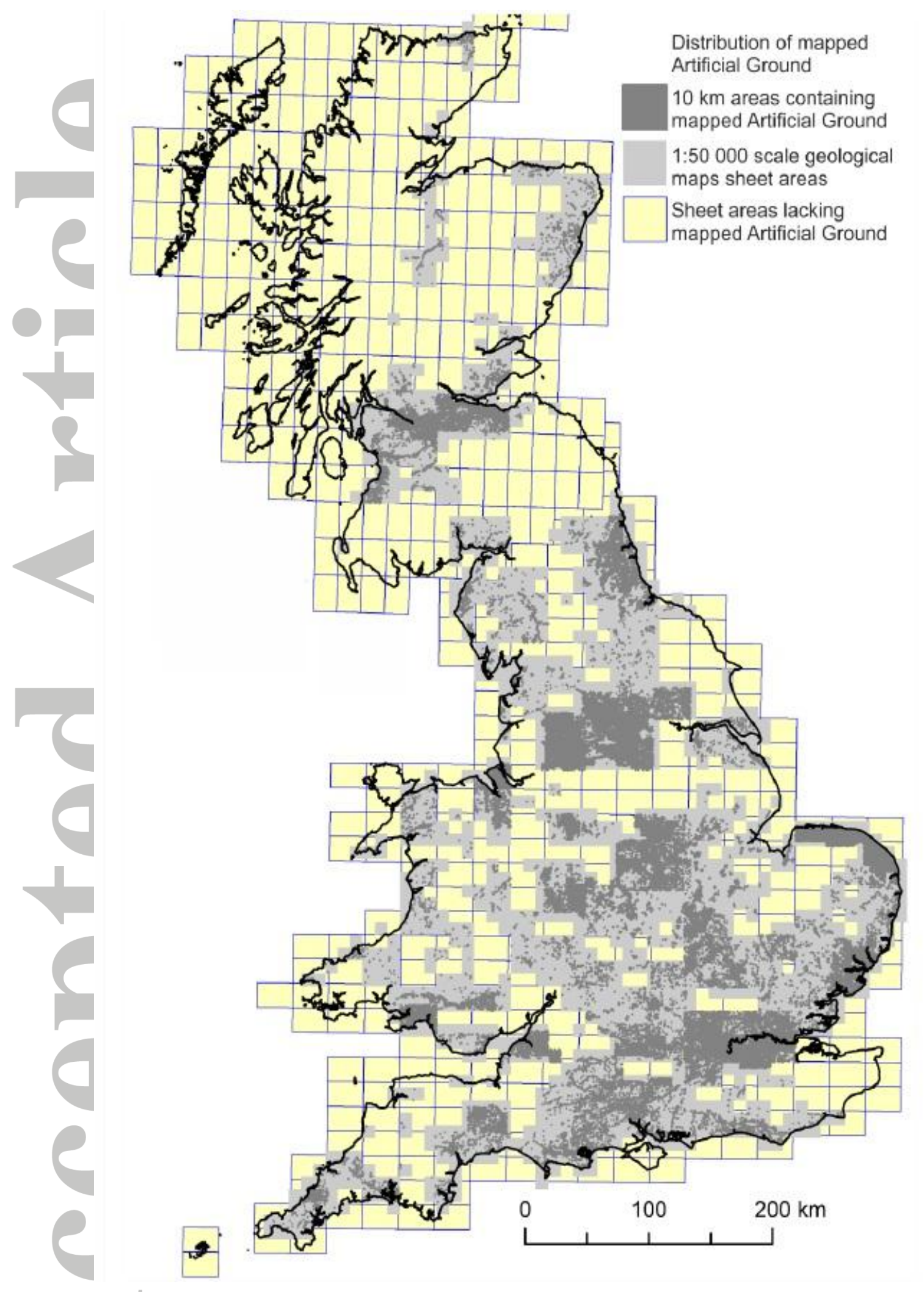

Figure 8. The mapped distribution of artificial ground in Great Britain (from Price et al., 2011 and OS Topography @ Crown Copyright. All rights reserved. 100017897/2010. DiGMapGB BGS @ NERC). 